NBER WORKING PAPER SERIES

\title{
ZOMBIE CREDIT AND (DIS-)INFLATION: EVIDENCE FROM EUROPE
}

\author{
Viral V. Acharya \\ Matteo Crosignani \\ Tim Eisert \\ Christian Eufinger \\ Working Paper 27158 \\ http://www.nber.org/papers/w27158 \\ NATIONAL BUREAU OF ECONOMIC RESEARCH \\ 1050 Massachusetts Avenue \\ Cambridge, MA 02138 \\ May 2020
}

We thank Tobias Berg, Balint Horvath, Farzad Saidi, Sanjay Singh, seminar participants at Michigan Ross, NYU Stern, University of Illinois at Urbana-Champaign, Erasmus Rotterdam, the University of Duisburg, University of St. Gallen, the University of Technology Sydney, and conference participants at the 2019 JFI-Nova SBE Conference, the 5th IWH-FIN-FIRE Conference (Halle), and the Bank of Finland and CEPR Joint Conference on Monetary Economics and Reality. Eufinger gratefully acknowledges the financial support of the Department of Economy and Knowledge of the Generalitat de Catalunya (Ref. 2017 SGR 1244) and the State Research Agency (AEI) of the Spanish Ministry of Science, Innovation and Universities (MCIU) and the European Regional Development Fund (FEDER) - REF PROYECTO PGC2018-097335-AI00 (MCIU/AEI/FEDER, UE). The views expressed herein are those of the authors and do not necessarily reflect the views of the National Bureau of Economic Research.

NBER working papers are circulated for discussion and comment purposes. They have not been peer-reviewed or been subject to the review by the NBER Board of Directors that accompanies official NBER publications.

(C) 2020 by Viral V. Acharya, Matteo Crosignani, Tim Eisert, and Christian Eufinger. All rights reserved. Short sections of text, not to exceed two paragraphs, may be quoted without explicit permission provided that full credit, including $\odot$ notice, is given to the source. 
Zombie Credit and (Dis-)Inflation: Evidence from Europe

Viral V. Acharya, Matteo Crosignani, Tim Eisert, and Christian Eufinger

NBER Working Paper No. 27158

May 2020

JEL No. E31,E44,G21

\section{ABSTRACT}

We show that cheap credit to impaired firms has a disinflationary effect. By helping distressed firms to stay afloat, "zombie credit" can create excess production capacity, and in turn, put downward pressure on markups and prices. We test this mechanism exploiting granular inflation and firm-level data from twelve European countries. In the cross-section of industries and countries, we find that a rise of zombie credit is associated with a decrease in firm defaults and entries, firm markups and product prices; lower productivity; and, an increase in aggregate sales as well as material and labor cost. These results hold at the firm-level, where we document spillover effects to healthy firms in markets with high zombie credit. Our partial equilibrium estimates suggest that without a rise in zombie credit post 2012, annual inflation in Europe during 2012-2016 would have been 0.45 percentage points higher.

Viral V. Acharya

Stern School of Business

New York University

44 West 4th Street, Suite 9-65

New York, NY 10012

and CEPR

and also NBER

vacharya@stern.nyu.edu

Matteo Crosignani

University of Michigan

Ross School of Business

mcrosign@gmail.com
Tim Eisert

Erasmus University Rotterdam

Burg. Oudlaan 50 / PO Box 1738

3000 DR Rotterdam

The Netherlands

eisert@ese.eur.nl

Christian Eufinger

IESE Business School

Avinguda de Pearson, 2108034

Barcelona

Spain

ceufinger@iese.edu 


\section{Introduction}

More than ten years after the global financial crisis, Europe's economic growth and inflation remain depressed, even though the European Central Bank (ECB) and other European central banks provided substantial monetary stimulus, including negative deposit rates, longer-term refinancing operations, and large-scale asset purchase programs. In former ECB President Mario Draghi's own words, "although we have seen the successful transmission of monetary policy to financing conditions, and from financing conditions to GDP and employment, the final legs of the transmission process to wages and inflation have been slower than we expected. Wage growth is now strengthening as slack in the labor market diminishes. But the pass-through from wages to prices remains weak."1

Europe's "missing inflation puzzle" bears a striking resemblance to Japan's "lost decades." Besides a deflationary pressure, both economies have been characterized by ultra accommodative central bank policies and zombie lending (i.e, cheap credit to impaired firms) by undercapitalized banks (see Caballero et al., 2008, Giannetti and Simonov, 2013, and Acharya et al., 2019). Along with search-for-yield behavior of investors, these forces have collectively pushed borrowing costs to record lows, even for high-risk firms. ${ }^{2}$ The glut of cheap debt has allowed many struggling firms to stay afloat, leading to a "zombification" of the economy (e.g., Borio and Hofmann, 2017 and Banerjee and Hofmann, 2018).

In this paper, we provide an explanation for the co-occurrence of the rise of zombie credit and low inflation shown in Figure 1. Building on Caballero et al. (2008), we illustrate in a simple model that a rise in zombie credit, by keeping alive distressed firms that would otherwise default, slows down the adjustment in the production capacity. Following a negative demand shock, the excess capacity puts downward pressure on product prices and thereby

\footnotetext{
${ }^{1}$ See Mario Draghi's speech "Twenty Years of the ECB's monetary policy" at the ECB Forum on Central Banking in Sintra on June 18, 2019. The speech is available at www.ecb.europa.eu.

${ }^{2}$ Since 2012, the average yield on European corporate junk bonds dropped by roughly two-thirds (with some junk bonds even starting to trade at sub-zero yields), while the ECB's cost-of-borrowing indicator for corporate loans more than halved. Sources: https://fred.stlouisfed.org/series/BAMLHE00EHYIEY, http://sdw.ecb.europa.eu/quickview.do?SERIES_KEY=124.MIR.M.U2.B.A2I.AM.R.A.2240.EUR.N, and "Sub-Zero Yields Start Taking Hold in Europe's Junk-Bond Market", Bloomberg, July 9, 2019.
} 


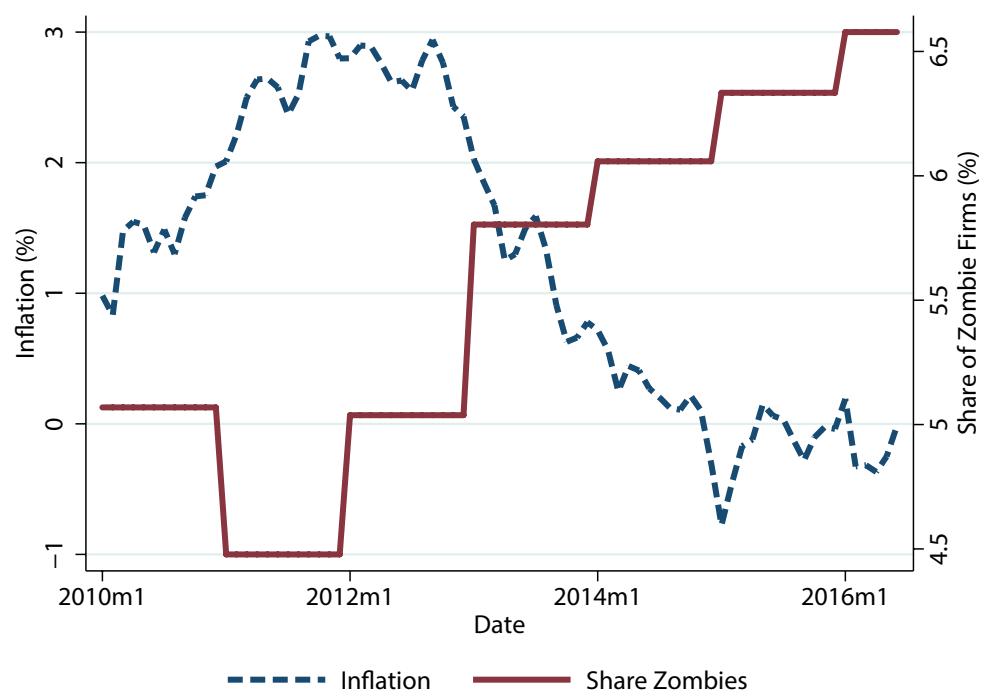

Figure 1: Zombie Credit and Inflation. This figure shows the year-over-year (yoy) growth of the CPI on the left axis and the asset-weighted share of zombie firms on the right axis in our sample. A firm is classified as zombie if it is low-quality (i.e., above median leverage and below median interest coverage ratio) and receives subsidized credit (interest expenses/debt smaller than that of the highest quality firms in a given year). Sources: Eurostat, Amadeus.

lowers inflation. $^{3}$ We test this channel using granular inflation and firm-level data for 1.1 million firms from 12 European countries across 65 industries. This data set allows us to observe product-level prices and detailed firm-level characteristics.

Our zombie credit channel mechanism is consistent with a model where firms, potential entrants and incumbents, draw a productivity parameter every period and set prices to exploit their market power. If its productivity realization is high, an incumbent firms is more likely to survive and a potential entrant firm is more likely to enter. If the realization is low, an incumbent firm is more likely to default and a potential entrant firm is less likely to enter. Following a negative demand shock and the resulting price decline, zombie credit keeps alive some firms that would otherwise default, weakening the downward adjustment

\footnotetext{
${ }^{3}$ For example, the Italian concrete and cement industry suffered from a global demand shock in 2008 . Many firms subsequently struggled to pay interests and relied on their banks to remain alive and produce. The CEO of Cementir, one of the industry leaders in Italy, stated in 2017 that "in Italy, in the cement industry, we have zombies kept alive by banks. [...] Banks do everything they can to keep these zombies alive to avoid realizing losses on their balance sheets." Industry representatives obtained in 2017 a Senate hearing (link) to discuss the ongoing crisis. In that hearing, they stated that "the excessive productive capacity caused an unprecedented price competition that, in turn, caused firms to realize large losses."
} 
in the number of active firms. The resulting excess production capacity puts downward pressure on firms' markups and product prices. In equilibrium, zombie credit causes (i) a reduction in firm default and entry, firm markups, product prices, and firm productivity; and (ii) an increase in sales, number of active firms, and input costs.

The empirical analysis is based on a new data set, obtained by combining product-level inflation data from Eurostat with firm-level accounting data from Bureau van Dijk's Amadeus. Using input-output linking tables, we calculate inflation at the industry-level from productlevel inflation data. Using Amadeus data, we identify zombie firms as firms that meet two criteria: (i) the interest coverage ratio is below the median and the leverage ratio is above the median - where medians are calculated at the industry-country level - and (ii) the cost of debt financing is lower than the cost paid by the most creditworthy comparable firms. Zombie firms' ex-post financial and real outcomes suggest that their access to cheap credit is not driven by a positive future outlook. In particular, while low-quality non-zombie firms on average deleveraged and maintained a stable profitability, zombie firms increased their leverage and experienced a drop in their profitability.

Our analysis in the cross section of countries and industries supports the zombie credit channel. We find that industry-country pairs (henceforth called "markets") that experience an increase in the share of zombie firms subsequently have: (i) fewer firm defaults and entries, (ii) more active firms, (iii) higher sales growth, (iv) higher input costs (material and labor costs), (v) lower productivity, (vi) lower markups, and (vii) lower inflation growth compared with markets with a lower prevalence of zombie firms. Our partial equilibrium estimates suggest that without a rise in zombie credit post 2012, annual inflation in Europe during 2012-2016 would have been 0.45 percentage points higher.

Our specifications include country-industry, country-year, and industry-year fixed effects to capture potential omitted variables such as country- and industry-specific shocks. The positive correlation between zombie credit and aggregate sales growth suggests that the negative correlation between zombie credit and inflation is not driven by lower demand in markets with more zombie credit. The negative correlation with productivity suggests that zombie credit is extended to actual zombie firms and not to firms that are only temporarily weak. The positive correlation with input costs confirms the zombie credit channel as more firms 
compete for the same factor inputs driving up their prices. To further mitigate endogeneity concerns, we instrument a market's zombie share with the lagged average Tier-1 capital ratio of the banks connected to the firms in this market. ${ }^{4}$ Our instrumental variable regression estimates confirm the negative effect of the share of zombie firms on inflation.

Finally, at the firm level, we document that the increased presence of zombie firms affects healthy firms active in the same market. In particular, we find that healthy firms that compete with a growing number of zombie firms have lower markups, profitability, and sales growth, as well as higher input costs. These correlations are consistent with healthy firms trying to prevent a drop in market share and capacity utilization by pricing more aggressively.

The remainder of the paper is structured as follows. Section 2 reviews the related literature. Section 3 presents the intuition linking zombie credit to inflation. We present the formal model in Appendix A. Section 4 illustrates our data and empirical work. Section 5 and Section 6 show our empirical analysis at the industry-country level and at the firm level, respectively. Section 7 presents robustness checks. Section 8 concludes.

\section{Related Literature}

Our paper contributes to three strands of literature. First, our paper relates to the literature on zombie credit, started with the evidence from Japan in the 1990s. In that context, Peek and Rosengren (2005) document that banks close to the regulatory capital constraint extended credit to their weak borrowers to avoid realizing losses on outstanding loans. Caballero et al. (2008) show that this zombie lending affected healthy firms, reducing their investment and employment growth. Giannetti and Simonov (2013) find that capital injections can stop zombie lending if they are large enough. A few recent papers show that similar dynamics are at work in Europe in the aftermath of its sovereign debt crisis. Acharya et al. (2019) show that the ECB's Outright Monetary Transactions (OMT) program induced

\footnotetext{
${ }^{4}$ The intuition behind this instrument is that weakly-capitalized banks have strong zombie lending incentives (see, e.g., Schivardi et al., 2017, Acharya et al., 2019, and Blattner et al., 2019).
} 
zombie lending by banks that remained weakly-capitalized. Schivardi et al. (2017) confirm that non-viable Italian firms obtained favorable bank credit from 2004 to 2013. Finally, using Portuguese data, Blattner et al. (2019) show that these distorted lending decisions caused a decline in productivity. For OECD countries, Adalet McGowan et al. (2018) show that the share of zombie firms increased over the period 2003-2013 and that the resulting market congestion is associated with lower investment and employment growth. Similarly, using firm-level data on listed firms in 14 advanced economies, Banerjee and Hofmann (2018) document a rise in the prevalence of zombie firms since the late 1980s, which they link to reduced financial pressure due to lower interest rates. We contribute to this literature by documenting the effect of zombie credit on firm markups and inflation.

Second, our paper relates to the literature on the effect of competition on firm price setting behavior and inflation. Campbell and Hopenhayn (2005), Lewis and Poilly (2012), and Lewis and Stevens (2015) show that markups are negatively related to the number of competitors in an industry. Aghion et al. (2018) find that the monetary easing induced by the OMT program announcement fostered growth especially for credit-constrained firms, and more so for a high degree of product market competition. The authors argue that, if competition is high, weak firms can only avoid exit when funding is readily available. These findings support the notion that zombie credit, and a resulting lower exit rate, can lead to excess capacity, which puts downward pressure on markups and prices.

Third, our paper adds to literature on the impact of financial frictions on inflation dynamics. Chevalier and Scharfstein (1996) highlight a "liquidity squeeze channel," arguing that liquidity-constrained firms have an incentive to raise prices to increase their current cash flows (assuming sticky customer relationships). Gilchrist et al. (2017) and de Almeida (2015) incorporate this mechanism into a general equilibrium model to explain the pricing behavior of U.S. and European firms in response to the 2007-08 financial crisis, respectively. Barth III and Ramey (2001) suggest the "cost channel" as a possible explanation for an increase (decrease) in inflation after a monetary tightening (loosening), which suggests that firms' pricing decisions are related to credit conditions as firms depend on credit to finance production. Christiano et al. (2015) argue, using a New Keynesian model, that the cost channel helps to explain the only modest disinflation in the U.S. during the Great Recession. 


\section{Mechanism from Zombie Credit to (Dis-)Inflation}

In this section, we describe the macroeconomic effects of zombie credit. In Appendix A, we present a formal model which develops a framework similar to Caballero et al. (2008).

Consider an environment with imperfect competition among firms that produce a single good. The demand for this good is exogenous. The supply is the sum of the production by incumbent and entrant firms. Incumbent and potential entrants are subject to an idiosyncratic shock. Incumbent firms that receive a bad shock might be forced to exit and entrant firms that receive a good shock might enter. In equilibrium, holding demand constant, a higher number of firms leads to a more competitive market and, therefore, a lower price.

Suppose the economy is in a steady state, namely the number of firms that default each period is exactly offset by the number of entrant firms. The equilibrium is illustrated by $A$ in Figure 2, where the exogenous demand is equal to the production by the constant number of incumbent firms. To illustrate the effect of zombie credit, we analyze how the economy transitions to a new equilibrium following a demand shock that reduces the demand to $D^{\prime}$.

In the case with no zombie credit, the demand shock causes the price and quantity to decrease along the supply curve $S$ to the new equilibrium $N$. The demand shock causes a direct drop in price making the economy less attractive for both entrant and incumbent firms. More incumbent firms default and fewer potential entrant firms enter. The lower number of incumbent firms has a positive effect on price, but not enough to offset the initial decline.

In the case with zombie credit, the demand shock again causes the equilibrium price and quantity to decrease, but this time along a flatter supply curve $S^{Z}$ to the new equilibrium $Z$. The shock causes a direct drop in price making the economy less attractive for both entrant and incumbent firms. Similar to the adjustment with no zombie credit, fewer potential entrant firms enter. However, there is a weaker adjustment through exit as zombie credit keeps afloat some incumbent firms that would otherwise default. The result is a flatter supply curve: a reduction in price leads to a muted effect on quantities.

More formally, consider a linear demand $P=\alpha-Q$. Given that the good is produced by surviving incumbent firms and entrant firms, a demand shock (lower $\alpha$ ) affects the price 


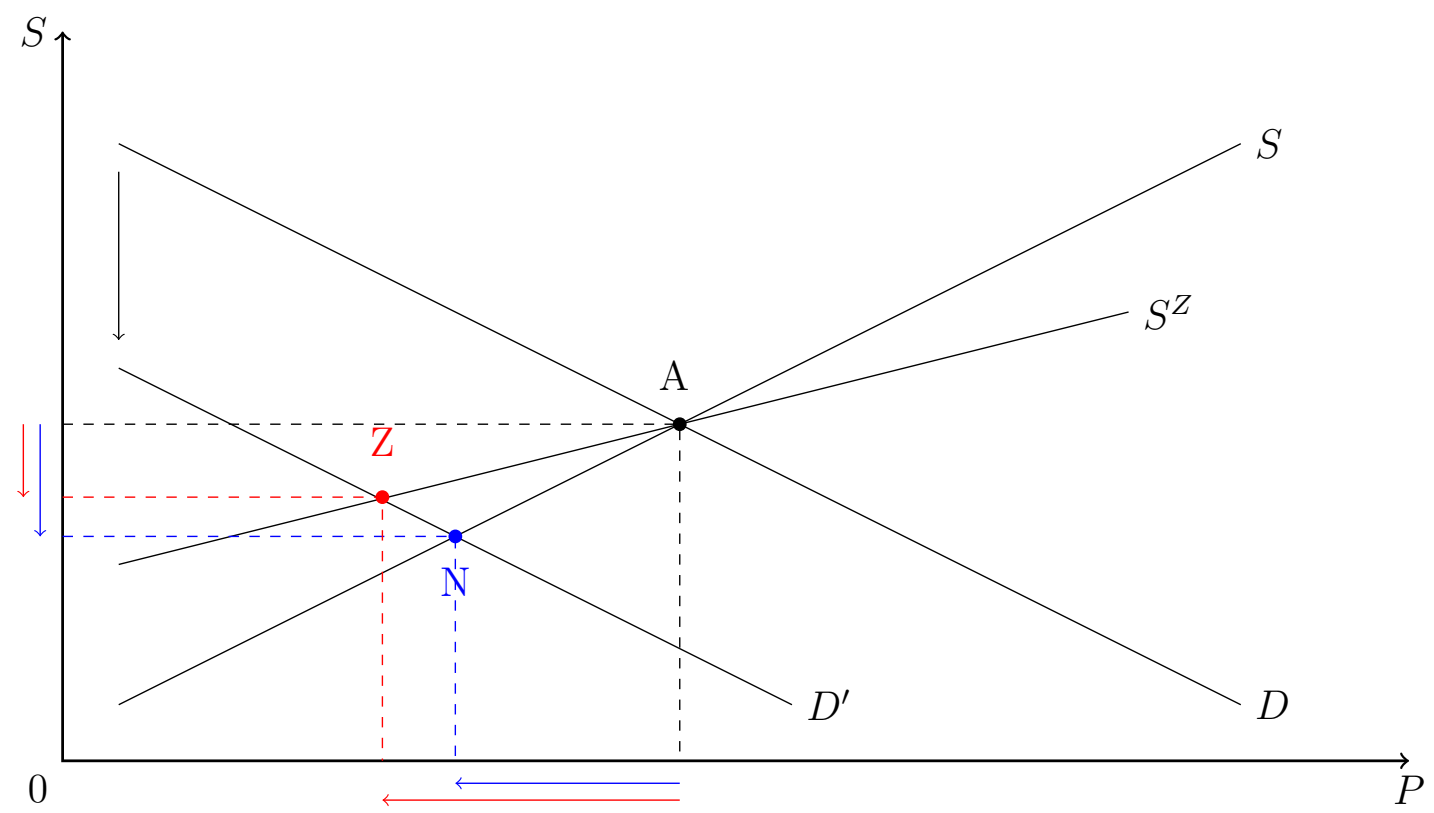

Figure 2: Intuition. This figure shows how zombie credit affects the equilibrium quantity and price.

of the good in three ways:

$$
\frac{d P}{d \alpha}=\underbrace{\frac{\partial P}{\partial \alpha}}_{>0}+\underbrace{\frac{\partial P}{\partial E n t r y} \frac{\partial E n t r y}{\partial \alpha}}_{<0}+\underbrace{\frac{\partial P}{\partial E x i t} \frac{\partial E x i t}{\partial \alpha}}_{=0 \text { with zombie credit }} .
$$

First, the direct effect: a lower demand (lower $\alpha$ ) reduces the equilibrium price. Second, the offsetting indirect effect through entry: a lower price causes fewer firms to enter, increasing the equilibrium price. Third, the offsetting indirect effect through exit: a lower price causes more firms to default, increasing the equilibrium price. The last two equilibrium effects only partially offset the direct effect. Crucially, in an economy with zombie credit, the equilibrium effect through exit can be considered as being shut down.

This mechanism can also be adapted to a similar economy where firms are setting prices in the input markets. In this case, zombie credit causes "too many" firms to compete for the same inputs (e.g., labor and materials), increasing their prices.

In sum, zombie credit causes (i) a reduction in firm defaults and entry, firm markups, product prices, and productivity; and, (ii) an increase in sales, number of active firms, and input costs. In the remainder of the paper, we test these predictions in the data. In our empirical strategy, we compare quantities and prices in markets with a high versus low 
prevalence of zombie firms. In other words, following Figure 2, we compare equilibria in markets that, because the heterogeneity in the prevalence of zombie firms, have a different slope of the supply curve.

In the next section, we (i) define a "market" as an industry-country pair, and (ii) measure the market-level prevalence of zombie firms in the data. Consistent with the model, we show that markets with a high prevalence of zombie firms have lower firm default, entry, markups, productivity, and product prices; and, higher sales, number of active firms, and input costs (labor and material costs) compared with markets with a low prevalence of zombie firms.

\section{Data and Empirical Work}

In this section, we describe our data and our strategy to identify zombie firms.

\subsection{Data}

Our data set combines detailed firm level and product inflation data. The firm level data are financial information and firm characteristics from Bureau van Dijk's (BvD) Amadeus database. This database has information about 21 million public and private companies from 34 countries, including all EU countries. BvD obtains the data, which is initially collected by local Chambers of Commerce, through roughly 40 information providers including business registers. Kalemli-Ozcan et al. (2015) show for selected European countries that Amadeus covers roughly $75-80 \%$ of the economic activity reported in Eurostat.

The inflation data are from Eurostat, which provides information for various consumer price indices for all European countries. This data set is very granular as we observe consumer prices at the five-digit COICOP (product category) level. We also use Eurostat to obtain official data on firm entry, firm exit, firm labor costs, and job's vacancy rates.

Note that the firm data are at the industry (NACE) level and the inflation data are at the product (COICOP) level. We use COICOP-NACE linking tables to merge these two data sets. More precisely, we use the linking tables to obtain inflation at the industry-country level, by calculating a weighted average of all COICOP (consumer price categories) that are related to a NACE (two digits) industry. Consider, for example, the textiles industry (NACE 
13). The Consumer Price Index (CPI) of this industry is a weighted average of the following COICOP categories: (i) clothing, (ii) furniture and furnishings, carpets and other floor coverings, (iii) household textiles, (iv) goods and services for routine household maintenance, and (v) other major durables for recreation and culture. Following the literature, we exclude utilities and financial and insurance industries from the sample. With this procedure, we obtain a measure of the monthly CPI at the industry-country level.

Our final sample consists of 1,167,460 firms for 12 European countries and 65 industries. The twelve European countries are Austria, Belgium, Germany, Denmark, Spain, Finland, France, Italy, Poland, Portugal, Sweden, and Slovakia.

\subsection{Identifying Zombie Firms}

Following Caballero et al. (2008) and Acharya et al. (2019), we define zombie firms as lowquality firms that receive debt financing at "very low" interest rates.

More specifically, we classify a firm as zombie firm if it meets two criteria. First, the firm has an interest coverage ratio below the median and a leverage ratio above the median, where the medians are calculated at the industry-country-year level. ${ }^{5}$ Second, the firm obtains credit at very low interest rates, i.e. the ratio of its interest expenses relative to the sum of its outstanding loans, credit, and bonds in a given year is below the interest paid by the most creditworthy firms, namely AAA-rated firms in the same year in our sample. ${ }^{6}$

Figure 1 shows that the share of zombie firms in our sample increased from roughly $4.5 \%$ to $6.7 \%$ from 2012 to mid-2016. ${ }^{7}$ In Figure 3, we document that this rise of zombie firms is driven by low-quality firms obtaining credit at very low interest rates and not by firms that already enjoy access to cheap credit deteriorating in quality. The left panel shows that, while the share of low-quality firms is constant at roughly $27 \%$ during our sample period, the share of zombie firms relative to low-quality firms increased from $17.5 \%$ to $22 \%$ between 2012 and

\footnotetext{
${ }^{5}$ The firms' interest coverage ratio is EBIT/interest expense and the firms' leverage ratio is (loans + short-term credit + long-term debt)/total assets.

${ }^{6}$ We infer ratings of firms from their interest coverage ratio as in Acharya et al. (2019).

${ }^{7}$ In Figure 9, we show that alternative zombie definitions yield a similar time-series pattern.
} 
Panel A: Share of Low-Quality and Zombie Firms

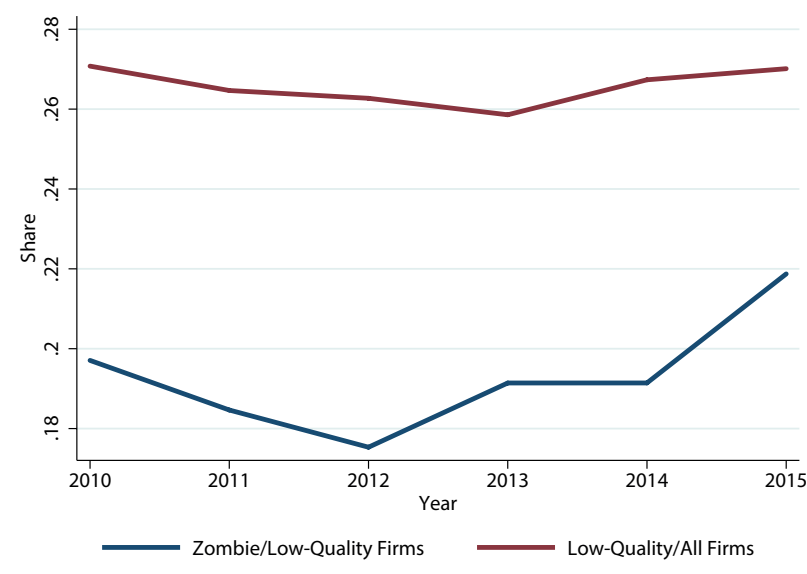

Panel B: Growth in Bank and Bond Financing

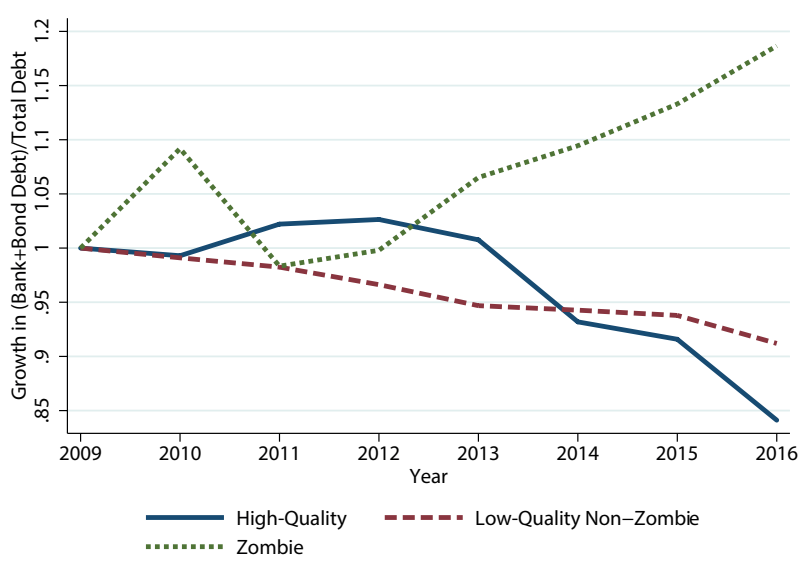

Figure 3: Firm Shares and Firm Financing. Panel A shows the share of zombie firms relative to all low-quality firms (blue line) and the share of low-quality firms relative to all firms (red line). Panel B shows the growth rate in bank and bond financing as a fraction of total debt relative to 2009 for zombie firms, low-quality non-zombie firms, and high-quality firms.

2015. The right panel shows that bank loans and bonds play an increasingly important role in the debt funding mix of zombie firms.

Table 1 presents descriptive statistics for our sample firms separately for high-quality firms, low-quality non-zombie firms, and zombie firms. Zombie firms are weaker than lowquality non-zombie firms along several observable dimensions. Zombie firms have on average a lower (even negative) interest coverage ratio, lower EBITDA margin (EBITDA/sales), lower net worth, less tangible assets to pledge for new loans, and a higher leverage. Nevertheless, these firms pay extremely low interest rates, even compared to high-quality firms. Given their high leverage and low profitability, these firms would have likely had a higher default rate if they had to pay a higher rate on their debt. Importantly, zombie firms are not younger nor more reliant on short-term credit compared with low-quality non-zombie firms, suggesting that our zombie definition does not simply capture early stage companies or companies reliant on short-term debt.

We also confirm that the firms that we classify as zombie are not temporarily weak firms, i.e. firms that "look weak" based on observable characteristics but that might actually have a promising future outlook that allows them to obtain cheap debt financing. To this end, we track their ex-post leverage, profitability, and default rates. In Figure 4, we plot the time-series evolution of leverage and EBITDA margin, respectively, for firms that have been 


\begin{tabular}{lccc} 
& & \multicolumn{2}{c}{ Low Quality } \\
\cline { 2 - 4 } & High-Quality & Non-Zombie & Zombie \\
\hline Markup & 1.13 & 1.05 & 1.01 \\
EBITDA Margin & 0.090 & 0.046 & 0.014 \\
Material Cost & 0.424 & 0.476 & 0.552 \\
Total Assets & 1.617 & 1.726 & 1.607 \\
Tangibility & 0.327 & 0.312 & 0.190 \\
IC Ratio & 4.90 & 1.01 & -0.53 \\
Net Worth & 0.224 & 0.107 & 0.069 \\
Leverage & 0.161 & 0.351 & 0.437 \\
ST Debt/Total Debt & 0.337 & 0.510 & 0.525 \\
Firm Age (years) & 17.5 & 17.3 & 17.8 \\
Interest Rate & 0.028 & 0.039 & 0.009 \\
\hline
\end{tabular}

Table 1: Summary Statistics. This table shows descriptive statistics for our sample firms. We split firms into high-quality, low-quality non-zombie, and zombie firms. A firm is classified as low-quality if it has below-median interest coverage ratio and above-median leverage, where medians are calculated at the industry-country-year level. A low-quality firm is classified as zombie if its interest rate paid on its debt financing is lower than the rate paid by AAA-rated firms year. Tangibility is fixed assets/assets. Leverage is debt/assets. Interest Coverage Ratio is EBIT/interest expense. Total assets is measured in million euro. The definition of firm markup is discussed in Appendix C. Material cost is material input cost/turnover. Net Worth is total shareholders funds and liabilities-current and non current liabilities-cash, divided by assets.

zombies continuously since 2012 (solid line) and low-quality firms that were never classified as zombies (dashed line). Panel A shows that, starting in 2011, zombie firms increased their leverage as they obtained cheap debt financing. In contrast, low-quality non-zombie reduced their leverage during the same period. Panel B shows a significant drop in profitability for zombie firms compared with low-quality non-zombie firms, which maintained their EBITDA margin roughly around its 2009 level.

In Figure 5, we analyze ex-post defaults, both non-parametrically in Panel A and parametrically in Panel B. Panel A shows that the default rate of zombie firms increased toward the end of the sample period, suggesting that (at least some) zombie firms were not able to eventually avoid default despite their cheap debt financing. We test this default pattern by estimating, in the subsample of low-quality firms, the following specification separately for every year $\tau$ :

$$
\text { Default }_{i t}=\alpha+\beta_{\tau} \mathcal{I}_{t \tau} \times \text { Zombie }_{i t}+\gamma X_{i t}+\eta_{j c t}+\epsilon_{i t},
$$

where $i$ is a firm and $t$ is a year. $\mathcal{I}_{t \tau}$ is a yearly indicator variable equal to 1 if $t=\tau$ and 0 otherwise and $\eta_{j c t}$ are industry-country-year fixed effects. The vector $X_{i t}$ includes 
Panel A: Evolution of Leverage

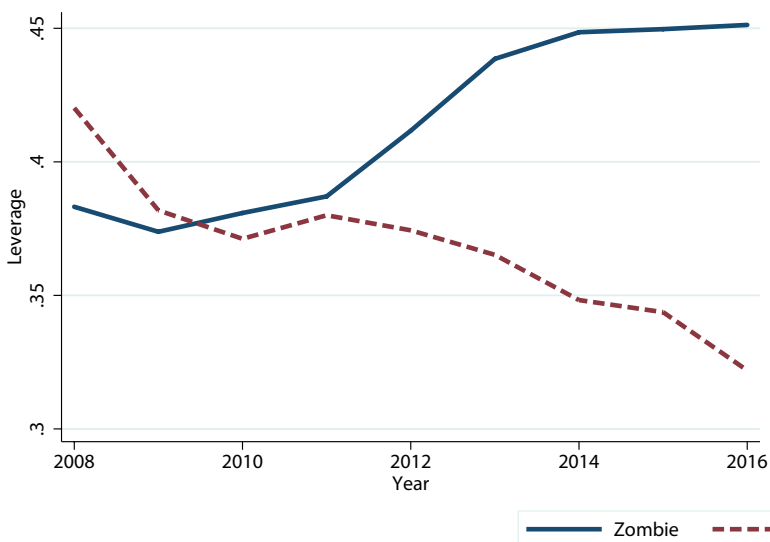

Panel B: Evolution of EBITDA/Assets

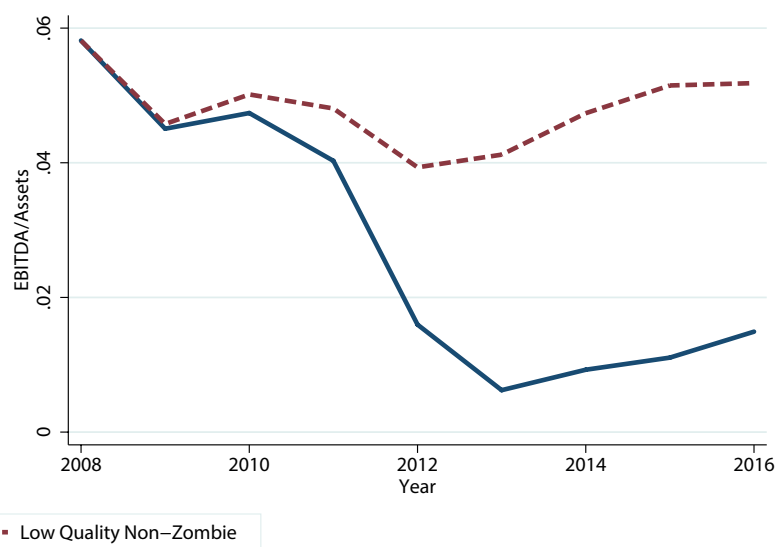

Figure 4: Ex-Post Firm Leverage and Profitability. This figure shows the ex-post evolution of leverage and profitability for zombie firms (firms that have been zombies continuously since 2012) and lowquality non-zombie firms (low-quality non-zombie firms that were never classified as zombies). Panel A shows the evolution of the asset-weighted leverage and Panel B shows the evolution of the asset-weighted EBITDA/Assets ratio.

Panel A: Cumulative Default Rates

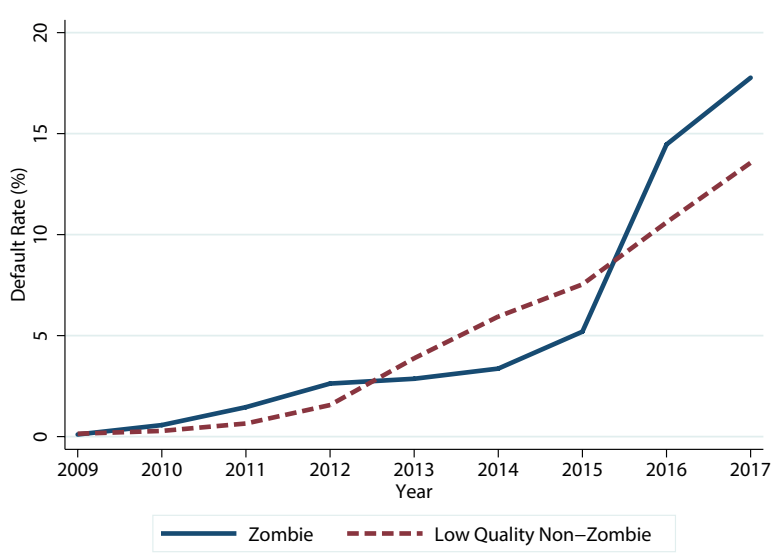

Panel B: Default Rates Regression

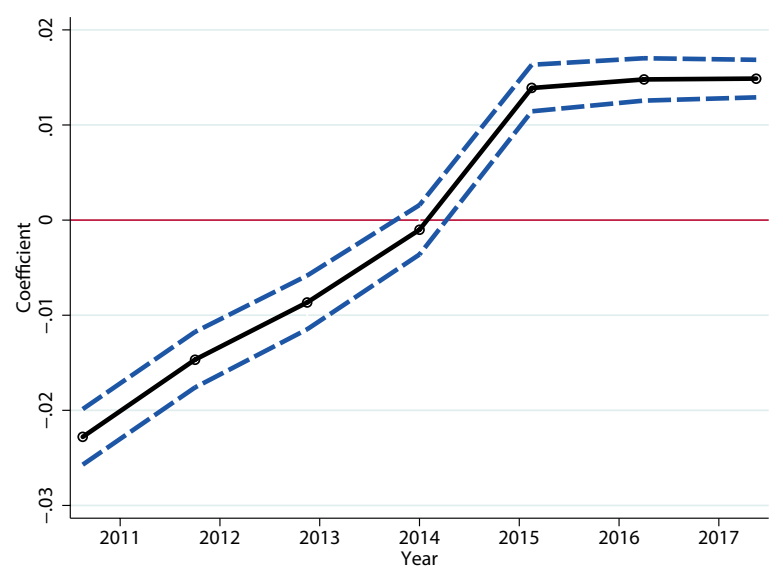

Figure 5: Ex-Post Firm Default Rates. Panel A shows the cumulative ex-post default rate of zombie firms (firms that have been zombies continuously since at least 2012) and low-quality non-zombie firms (low-quality non-zombie firms that were never classified as zombies). Panel B shows the coefficients from specification (1). 
the uninteracted Zombie variable as well as other firm characteristics. The coefficient $\beta_{\tau}$, shown in Panel B of Figure 5, confirms that zombie firms default more than non-zombie firms toward the end of our sample period.

These figures suggest that zombie firms, as they obtained continued cheap debt financing, underperformed other firms, including low-quality non-zombie firms. This ex-post evidence validates our measure of zombie firms, suggesting that our measure does not capture temporarily weak firms that are actually positive NPV projects for the lender.

\section{Industry-Country Level Evidence}

In this section, we test the model predictions at the industry-country ("market") level. In Section 5.1, we document a robust negative correlation between the presence of zombie firms and product inflation. In Section 5.2, we show that this correlation is not driven by lower demand driving both zombie presence and inflation. In Section 5.3, we test the other model predictions, namely the effect of the presence of zombie firms on markups, sales growth, number of active firms, default and entry rates, productivity, and input costs.

\subsection{Zombie Firms and Inflation}

We start by providing non-parametric evidence on the correlation, across markets, between the share of zombie firms and inflation, our main variable of interest. Figure 6 shows the year-over-year CPI growth separately for markets with a high (above median) and low (below median) growth of zombie firms over our sample period. Consistent with the rise of the share of zombie firms in the aggregate starting in 2012, we see that beginning in mid-2012, markets with a higher increase in the share of zombie firms experience a decline in CPI growth compared with markets with a lower increase in zombies firms. ${ }^{8}$ The timing of the

\footnotetext{
${ }^{8}$ In Figure B.1 in the appendix, we show that our aggregate measure of inflation, calculated from our disaggregated market-level measure of inflation, closely tracks the official inflation for our sample countries. The difference becomes even smaller when we exclude outliers, that is, markets that have an absolute value of annual CPI growth of more than $50 \%$ (five markets in total). All regression results are insensitive to
} 


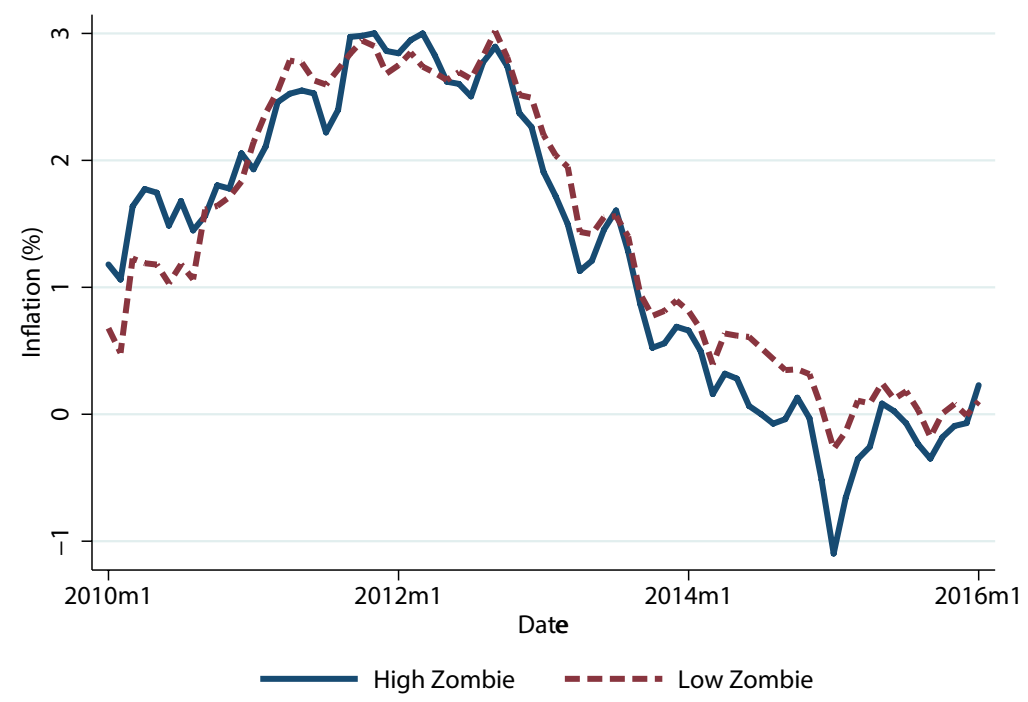

Figure 6: Inflation Dynamics, Non-Parametric Evidence. This figure shows inflation (year-over-year CPI growth) at monthly frequency for markets that experienced an above median (High Zombie) and below median (Low Zombie) increase in the asset-weighted share of zombie firms between 2009 and 2014.

reversal of the inflation dynamics coincides with the adoption of extraordinary monetary easing measures, including negative rates, by the ECB and other national central banks.

Next, we estimate the following specification:

$$
Y_{h j t}=\beta \times \text { Share } \text { Zombies }_{h j t-1}+\gamma_{h t}+\nu_{j t}+\mu_{j h}+\epsilon_{h j t},
$$

where the unit of observation is industry $j$, country $h$, and year $t$. $Y_{h j t}$ is the annual CPI growth rate. Our key explanatory variable is the lagged (asset-weighted) share of zombie firms in a particular market: Share $Z_{\text {ombies }}{ }_{h t-1}$. In the most conservative specification, we control for industry-country, country-year, and industry-year fixed effects. Country-year fixed effects absorb all shocks at the national level (e.g., changes in tax rates and national regulations) that could affect firms' policies and performance. Industry-year fixed effects absorb all shocks at the industry level (e.g., global demand shocks). Country-industry fixed effects control for time-invariant industry-country characteristics.

The estimation results in Table 2 confirm that markets that experience an increase in

whether we include or exclude these outlier markets (see Table B.1). 


\begin{tabular}{lcccc} 
& $\Delta \mathrm{CPI}$ & $\Delta \mathrm{CPI}$ & $\Delta \mathrm{CPI}$ & $\Delta \mathrm{CPI}$ \\
\hline Share Zombies & $-0.021^{* *}$ & $-0.017^{* *}$ & $-0.025^{* * *}$ & $-0.021^{* * *}$ \\
& $(0.008)$ & $(0.007)$ & $(0.009)$ & $(0.007)$ \\
\hline Observations & 3,880 & 3,880 & 3,880 & 3,880 \\
R-squared & 0.491 & 0.723 & 0.522 & 0.754 \\
\hline Country-Industry FE & $\checkmark$ & $\checkmark$ & $\checkmark$ & $\checkmark$ \\
Year FE & $\checkmark$ & & & \\
Industry-Year FE & & $\checkmark$ & & $\checkmark$ \\
Country-Year FE & & & $\checkmark$ & $\checkmark$ \\
\hline
\end{tabular}

Table 2: Inflation: Industry-Country Evidence. This table presents estimation results from specification (2). The dependent variable is the annual CPI growth rate (inflation) from $t$ to $t+1$. Share Zombies measures the asset-weighted share of zombie firms in a particular market at $t$. A firm is classified as zombie if it is low-quality and paid advantageous interest rates (see Section 4.2 for more details). Standard errors are clustered at the industry-country level and reported in parentheses. ${ }^{* * *} \mathrm{p}<0.01,{ }^{* *} \mathrm{p}<0.05,{ }^{*} \mathrm{p}<0.1$.

the share of zombie firms subsequently have lower CPI growth. The estimated coefficient is remarkably stable as we add different layers of fixed effects. Based on the estimates in the last column, moving from the $10^{\text {th }}$ to the $90^{\text {th }}$ percentile of the zombie share distribution (an increase of 11 percentage points) is associated with a 0.23 percentage point lower inflation.

A simple counterfactual exercise shows that these magnitudes are economically significant. Suppose that the share of zombie firms remained at its 2012 level in each market. Using our estimates, we can (i) calculate, for each market, what the CPI growth would have been under this counterfactual scenario in the post-2012 period and (ii) aggregate these counterfactual inflation rates across all markets, using the CPI industry weights. We present the results in Figure 7, where the solid line is the observed inflation and the dashed line is the counterfactual inflation. With the obvious caveats of a partial equilibrium exercise, our estimates suggest that inflation would have been on average 0.45 percentage points higher if the share of zombies stayed at its 2012 level.

In Table 3, we present some examples of markets that experienced a large increase in the share of zombie firms in the post-2012 period. Consider, for example, the manufacturing industry in France, which saw a sharp increase in the share of zombie firms by $38.5 \% .^{9}$

\footnotetext{
${ }^{9}$ French non-financial companies are heavily indebted. In France, non-financial corporate debt, loans
} 


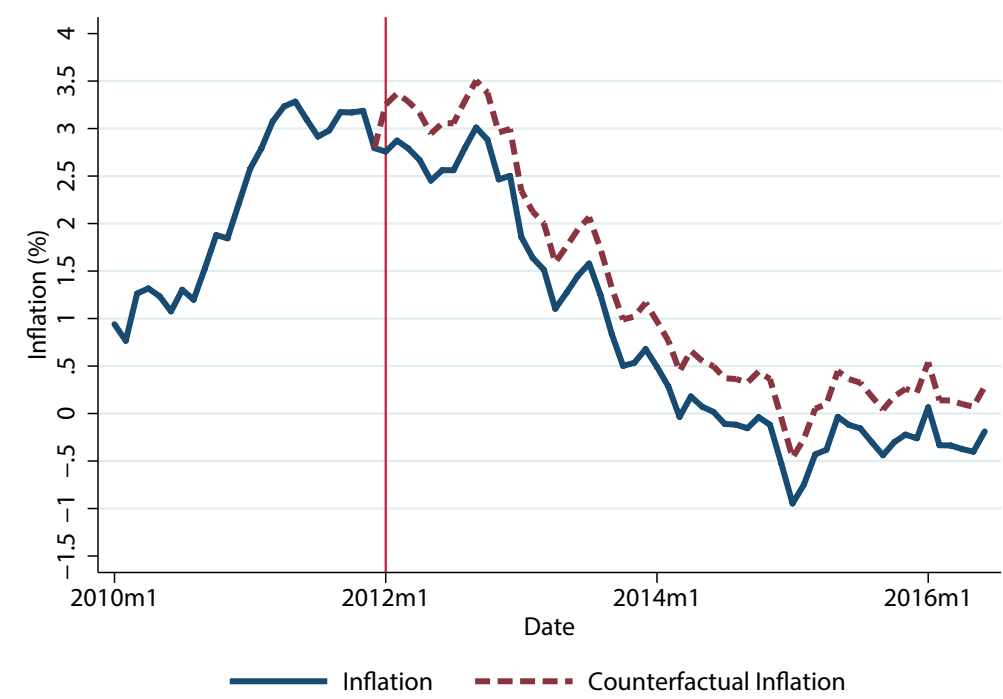

Figure 7: Inflation Counterfactual. This figure shows the actual inflation rate in our sample and a counterfactual inflation rate. The counterfactual inflation rate (at market-level) is measured as the inflation rate that would have prevailed from 2012 to 2016, if the share of zombie firms had stayed at the 2012 in each market. These values are aggregated across markets using actual weights for the aggregate CPI.

Panel A: Industries with Increase

\begin{tabular}{cccccc}
\hline Country & Industry & $\begin{array}{c}\text { CPI Growth } \\
(\%)\end{array}$ & $\begin{array}{c}\Delta \text { Share } \\
\text { Zombie }\end{array}$ & $\begin{array}{c}\text { Effect } \\
(\mathrm{pp})\end{array}$ & $\begin{array}{c}\text { Counterfactual } \\
\text { CPI Growth }(\%)\end{array}$ \\
\hline France & Manufacturing & -4.19 & 38.5 & -0.81 & -3.38 \\
Italy & Transportation and Storage & -0.30 & 28.41 & -0.60 & 0.30 \\
Portugal & Arts, Entertainment and Recreation & 0.58 & 28.3 & -0.60 & 1.18 \\
Slovenia & Manufacturing & -2.39 & 26.44 & -0.56 & -1.83 \\
Italy & Manufacturing & -2.60 & 22.44 & -0.47 & -2.13 \\
\hline
\end{tabular}

Panel B: Industries with Decrease

\begin{tabular}{cccc}
\hline & & CPI Growth & $\Delta$ Share \\
Country & Industry & $(\%)$ & Zombie \\
\hline France & Transportation and Storage & 2.00 & -54.7 \\
France & Other Service Activities & 2.90 & -34.9 \\
Spain & Information and Communication & 2.80 & -6.6 \\
Germany & Information and Communication & 2.70 & -1.0 \\
Germany & Manufacturing & 2.60 & -0.5 \\
\hline
\end{tabular}

Table 3: Inflation Counterfactuals, Examples. This table presents examples for some industries that saw a strong increase (Panel A) and decrease (Panel B) in the share of zombie firms after 2012. CPI growth is the actual CPI growth between 2012 and 2016 for the respective industry-country pair. $\Delta$ ShareZombie is the increase in the asset-weighted share of zombie firms post-2012. We use the coefficient -0.021 , taken from the most restrictive specification in Table 2 . The Effect is calculated as -0.021 ( $\Delta$ Share Zombie). The Counterfactual CPI growth shows what the inflation rate would have been without an increase in the share of zombie firms. 
Considering our estimates from Table 2, the CPI growth would have been 0.81 percentage points higher than the observed CPI growth in this market if the share of zombie firms had not increased post-2012.

\subsection{Are Our Results Driven By Lower Demand?}

We have documented, in the cross-section of markets, a negative correlation between the presence of zombie firms and inflation. This correlation is consistent with the mechanism outlined in Section 3: zombie credit allows some distressed firms to avoid default, increasing the productive capacity in their market. This higher productive capacity puts, in turn, a downward pressure on product prices. However, the negative correlation between the presence of zombie firms and inflation is also consistent with lower product demand, which might reduce inflation and increase the number of zombie firms.

We address this potential omitted variable bias in two ways. First, in Table 4, we estimate specification (2), where the dependent variable is sales growth. The estimation results document a positive correlation, in the cross-section of markets, between the presence of zombie firms and sales growth. This evidence is consistent with the zombie credit channel and inconsistent with a demand channel as the latter would predict lower sales growth in markets with high zombie prevalence.

Second, we run an instrumental variable (IV) regression, where we focus on the zombie lending incentives of weakly-capitalized banks as a predictor for the increase in the zombie prevalence. Besides search-for-yield behavior and ultra accommodative central bank policies, this zombie lending channel is identified in the literature as a main cause for the rise of zombie credit (see, e.g., Banerjee and Hofmann, 2018 and Acharya et al., 2019).

In particular, we instrument a market's share of zombie firms with the lagged average capitalization (measured as Tier 1 to risk-weighted assets ratio) of the banks connected to the firms in this market, weighted by the number of firm relationships. We denote this

and debt securities as a percentage of GDP amounts to 141\%, which is among the highest levels in Europe. Source: IMF Global Debt Database. 


\begin{tabular}{lcccc} 
& Sales Growth & Sales Growth & Sales Growth & Sales Growth \\
\hline Share Zombies & $0.287^{* *}$ & $0.400^{* * *}$ & $0.320^{* * *}$ & $0.420^{* * *}$ \\
& $(0.123)$ & $(0.148)$ & $(0.114)$ & $(0.129)$ \\
\hline Observations & 3,894 & 3,894 & 3,894 & 3,894 \\
R-squared & 0.179 & 0.251 & 0.409 & 0.476 \\
\hline Country-Industry FE & $\checkmark$ & $\checkmark$ & $\checkmark$ & $\checkmark$ \\
Year FE & $\checkmark$ & & & $\checkmark$ \\
Industry-Year FE & & $\checkmark$ & $\checkmark$ & $\checkmark$ \\
Country-Year FE & & & $\checkmark$ &
\end{tabular}

Table 4: Sales Growth: Industry-Country Evidence. This table presents estimation results from specification (2). The dependent variable is sales growth from $t$ to $t+1$. Share Zombies measures the asset-weighted share of zombie firms in a particular market at $t-1$. A firm is classified as zombie if it is low-quality and paid advantageous interest rates (see Section 4.2 for more details). Standard errors are clustered at the industry-country level and reported in parentheses. ${ }^{* * *} \mathrm{p}<0.01,{ }^{* *} \mathrm{p}<0.05,{ }^{*} \mathrm{p}<0.1$.

instrument as Average Tier-1 Ratio. This instrument is based on the idea, introduced in Peek and Rosengren (2005), that weakly-capitalized banks have an incentive to evergreen loans to distressed borrowers. ${ }^{10}$ By extending loans at very low interest rates, these banks provide their impaired borrowers with the liquidity necessary to meet payments on other outstanding loans. Thereby, these banks avoid (or at least defer) realizing immediate loan losses in the hope that the respective borrowers will eventually regain solvency. Schivardi et al. (2017), Acharya et al. (2019), and Blattner et al. (2019) provide evidence for such zombie lending behavior in Europe in the aftermath of the recent sovereign debt crisis. Figure 8 confirms this conjecture by documenting a pronounced negative relationship between a market's Average Tier-1 Ratio and its zombie share growth.

Of course, banks' capitalization is closely linked to the performance of the industries banks are exposed to. Specifically, a larger exposure to firms in sectors that experienced a strong negative demand shock could result in larger loan losses and thus lower capital levels. However, our analysis of data from the European Banking Authority's EU-wide stress tests and capital exercises shows that banks' capitalization is to a large extent determined by the value loss of their holdings of government bonds from stressed European countries during the

\footnotetext{
${ }^{10}$ Given that European firms are heavily reliant on bank credit, this instrument is particularly relevant in our setting.
} 


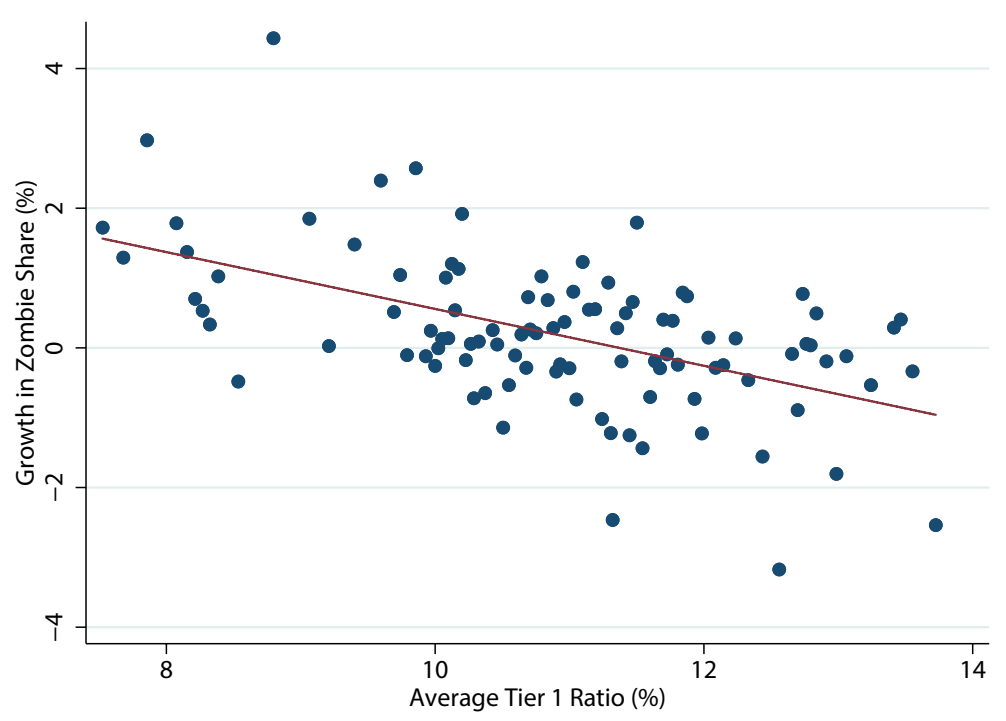

Figure 8: Bank Capitalization and Zombie Growth This figure presents a binscatter plot showing the relation between the lagged Tier-1 capital ratio (x-axis) and the growth in the share of zombie firms (y-axis). To calculate the the average Tier-1 capital ratio of an industry-country pair the number of firms a bank is connected to is used as weight.

recent sovereign debt crisis and not loan losses. In particular, the rank correlation between the banks' pre-crisis (i.e., 2009) sovereign debt holdings from stressed countries and their equity change between between 2009 and 2012 is -0.49 (linear correlation is -0.53).

In our preferred IV specification, we determine the bank-firm relationships using both Amadeus and DealScan (see Table 5, Column 1). As a robustness check, we redo our analysis (i) using bank-firm relationships solely from Amadeus (Column 2) and (ii) using bank-firm relationship from Dealscan in Italy (Amadeus does not contain bank-firm relationships for Italy) and from Amadeus in other countries (Column 3).

The first stage, shown in Panel B of Table 5, explains the share of zombie firms at time $t-1$ in a particular market (Share Zombies) using the market's Average Tier-1 Ratio at $t-2$, controlling for lagged market quality (i.e., its share of low-quality firms) as well as stringent sets of fixed effects. The instrument always has a negative and significant effect on Share Zombies. The F-statistic ranges between 13.9 and 14.6, while the p-value is always below 0.01 , confirming the strength of the instrument. In the second-stage estimation results, shown in Panel A of Table 5, we replace the Share Zombies with the predicted Share Zombies based on the first stage. The IV estimated coefficients confirm our results from Table 2, suggesting a causal negative effect of a market's share of zombies on inflation. 


\begin{tabular}{lccc} 
Panel A & $\Delta \mathrm{CPI}$ & $\Delta \mathrm{CPI}$ & $\Delta \mathrm{CPI}$ \\
\hline Share Zombies & $-0.196^{* *}$ & $-0.198^{* *}$ & $-0.194^{* *}$ \\
& $(0.096)$ & $(0.099)$ & $(0.096)$ \\
\hline Observations & 2,080 & 1,939 & 2,080 \\
\hline
\end{tabular}

\begin{tabular}{lccc} 
Panel B & Share Zombie & Share Zombie & Share Zombie \\
\hline Average Tier-1 Ratio & $-1.177^{* * *}$ & $-1.380^{* * *}$ & $-1.171^{* * *}$ \\
& $(0.310)$ & $(0.371)$ & $(0.307))$ \\
\hline F-Test & 14.6 & 13.9 & 14.5 \\
\hline Observations & 2,080 & 1,939 & 2,080 \\
R-squared & 0.747 & 0.748 & 0.747 \\
\hline Sample & Amadeus & Amadeus & Amadeus \\
& + DealScan & Only & + DealScan Italy \\
\hline Country-Industry FE & $\checkmark$ & $\checkmark$ & $\checkmark$ \\
Industry-Year FE & $\checkmark$ & $\checkmark$ & $\checkmark$ \\
Country-Year FE & $\checkmark$ & $\checkmark$ & $\checkmark$ \\
\hline
\end{tabular}

Table 5: Instrumental Variable Estimation. This table presents the estimation results from the IV specification. The dependent variable in the second stage is the annual CPI growth rate (inflation). Share Zombies measures the asset-weighted share of zombie firms at $t-1$. Average Tier-1 Ratio measures the average tier-1 ratio of banks (weighted by the number of firm relationships) that are related to firms in an industry-country at $t-1$. Bank relationships are determined using Amadeus and DealScan in Column 1, solely Amadeus in Column 2, and Amadeus and DealScan solely for Italian firms in Column 3. Standard errors clustered at the industry-country level reported in parentheses. ${ }^{* * *} \mathrm{p}<0.01,{ }^{* *} \mathrm{p}<0.05,{ }^{*} \mathrm{p}<0.1$.

The IV estimate of the inflation elasticity to the zombie share (-0.196) is about 9 times larger than the OLS estimate (-0.021). The IV estimate corresponds to the change in inflation due to changes in the zombie lending behavior of (weakly-capitalized) banks. The OLS estimate, however, corresponds to a regression of inflation on the change in the zombie share, induced by all zombie credit channels (e.g., zombie lending by banks, search-foryield behavior, and ultra accommodative central bank policies) and demand factors. When these factors are uncorrelated, the variations in other zombie credit factors and demand are equivalent to measurement error, and the OLS estimate is biased towards zero due to standard attenuation bias. We can use the magnitude of the OLS bias to backout the importance of the zombie lending channel relative to other zombie credit channels and the demand channel (see, e.g., Paravisini et al., 2015). In our setting, the magnitude of the attenuation bias increases with the fraction of the zombie share variation that is explained by other factors than the zombie lending channel. Based on the classic measurement error 


\begin{tabular}{lcccc} 
& $\Delta$ Markup & $\Delta$ Markup & $\Delta$ Markup & $\Delta$ Markup \\
\hline Share Zombies & $-0.052^{* *}$ & $-0.054^{* *}$ & $-0.057^{* *}$ & $-0.063^{* *}$ \\
& $(0.024)$ & $(0.026)$ & $(0.025)$ & $(0.027)$ \\
\hline Observations & 3,261 & 3,261 & 3,261 & 3,261 \\
R-squared & 0.148 & 0.315 & 0.172 & 0.337 \\
\hline Country-Industry FE & $\checkmark$ & $\checkmark$ & $\checkmark$ & $\checkmark$ \\
Year FE & $\checkmark$ & & & \\
Industry-Year FE & & $\checkmark$ & & $\checkmark$ \\
Country-Year FE & & & $\checkmark$ & $\checkmark$ \\
\hline
\end{tabular}

Table 6: Markups: Industry-Country Evidence. This table presents estimation results from specification (2). The dependent variable is the turnover-weighted change in markups from $t$ to $t+1$. Share Zombies measures the asset-weighted share of zombie firms in a particular market at $t$. A firm is classified as zombie if it is low-quality and paid advantageous interest rates (see Section 4.2 for more details). Standard errors are clustered at the industry-country level and reported in parentheses. ${ }^{* * *} \mathrm{p}<0.01,{ }^{* *} \mathrm{p}<0.05,{ }^{*} \mathrm{p}<0.1$.

bias formula, $\beta / \beta_{O L S}=1+\sigma_{o f}^{2} / \sigma_{z l}^{2}$, where $z l$ stands for zombie lending and of for other factors, our estimates indicate that the zombie lending channel explains roughly $11 \%$ of the total variation in the zombie share.

\subsection{Further Model Predictions}

In this section, using specification (2), we show that markets with a higher zombie prevalence display lower firm markups, more active firms, lower default and entry rates, higher input costs, and lower productivity compared with markets with a lower zombie prevalence.

In Table 6, we show that higher zombie prevalence is associated with lower firm markup. We measure firm markups following De Loecker and Warzynski (2012) and De Loecker and Eeckhout (2019), i.e. we rely on optimal input demand conditions obtained from standard cost minimization to determine markups for each firm. ${ }^{11}$ This approach has the advantage that it only requires firms' financial statements information and no assumptions on demand and how firms compete. Following De Loecker and Eeckhout (2019), we aggregate the firm markups in the respective market using the firms' turnover as weight. The estimated coefficients document lower markups in markets with a higher zombie share.

\footnotetext{
${ }^{11}$ See Appendix $\mathrm{C}$ for more details on the markup estimation.
} 
In Table 7, we show that a higher zombie prevalence is associated with more active firms, fewer firm defaults, and fewer firms entering a market. These variables are obtained from Eurostat that releases official data at the industry-country level over time. ${ }^{12}$ The intuition from our model is that a higher share of zombie firms in a market amounts to a higher number of firms that would be more likely to default without zombie credit. The resulting excess productive capacity reduces the product price and firm markups, making the market less attractive for potential entrants.

In Table 8, we show that a higher zombie prevalence is associated with higher input costs and lower productivity. The excessive productive capacity in markets with high zombie presence leads to a higher demand for labor and materials causing, in turn, higher material and labor costs. Panel A shows a positive correlation between the presence of zombie firms and material costs. Panel $\mathrm{B}$ shows that the correlation between the presence of zombie firms and labor costs only exists for markets with a high job vacancy rate, where High Vacancy is a dummy equal to one for industries with above median job vacancy rate. We use the annual change in the Eurostat Labour Cost Index to measure the firms' labor costs. ${ }^{13}$ The insignificant coefficient for Share Zombie suggests that the higher average labor cost for (some) zombie markets is indeed induced by a higher number of active firms and the resulting competition for inputs. Panel $\mathrm{C}$ shows a negative correlation between the presence of zombie firms and firms' average productivy, where the latter is measured as $\log ($ sales)2/3*log(employment)-1/3*log(fixed assets), following Caballero et al. (2008).

In the macro literature, there is no conclusive evidence of a positive relationship between cost inflation and price inflation, especially in recent years. In line with our mechanism, Del Negro et al. (2020) explain the recent disconnect between inflation and real activity with the recent muted reaction of prices to cost pressures. Taylor (2000) also document that

\footnotetext{
${ }^{12}$ We can also calculate firm default rates from Amadeus. In Table 11, we show that we obtain similar results on firm defaults if we rely on the Amadeus database to classify firms as defaulted.

${ }^{13}$ This index is designed to capture the labor cost pressure. The job vacancy rate is also calculated from Eurostat's job vacancy statistics and is defined as the number of job vacancies as a percentage of the sum of the number of occupied posts and job vacancies. Importantly, the labor cost index is provided at less granular industry classifications, which leads to a significant reduction in the number of observations.
} 


\begin{tabular}{lcccc} 
Panel A & $\Delta$ Active Firms & $\Delta$ Active Firms & $\Delta$ Active Firms & $\Delta$ Active Firms \\
\hline Share Zombies & $0.064^{* * *}$ & $0.074^{* * *}$ & $0.065^{* * *}$ & $0.075^{* * *}$ \\
& $(0.023)$ & $(0.025)$ & $(0.019)$ & $(0.020)$ \\
\hline Observations & 3,844 & 3,844 & 3,844 & 3,844 \\
R-squared & 0.475 & 0.529 & 0.625 & 0.675 \\
\hline & & & & \\
Panel B & Default & Default & Default & Default \\
\hline Share Zombies & $-0.016^{* *}$ & $-0.019^{* *}$ & $-0.017^{* *}$ & $-0.020^{* *}$ \\
& $(0.007)$ & $(0.009)$ & $(0.007)$ & $(0.008)$ \\
\hline Observations & 3,626 & 3,626 & 3,626 & 3,626 \\
R-squared & 0.828 & 0.842 & 0.872 & 0.885 \\
\hline & & & & Entry \\
Panel C & Entry & Entry & Entry & $-0.021^{* *}$ \\
\hline Share Zombies & $-0.024^{* *}$ & $-0.026^{* *}$ & $-0.021^{* *}$ & $(0.011)$ \\
& $(0.010)$ & $(0.012)$ & $(0.010)$ & 3,824 \\
\hline Observations & 3,824 & 3,824 & 3,824 & 0.895 \\
R-squared & 0.825 & 0.846 & 0.874 & $\checkmark$ \\
\hline & & & & $\checkmark$ \\
\hline Country-Industry FE & $\checkmark$ & $\checkmark$ & $\checkmark$ & $\checkmark$ \\
Year FE & $\checkmark$ & $\checkmark$ & $\checkmark$ & $\checkmark$ \\
Industry-Year FE & & & $\checkmark$ & $\checkmark$ \\
Country-Year FE & & & & $\checkmark$
\end{tabular}

Table 7: Number of Active Firms, Firm Defaults, and Firm Entries: Industry-Country Evidence. This table presents estimation results from specification (2). The dependent variable is the change in the number of firms (Panel A), the share of firm exits (Panel B), and the share of firm entries (Panel C). Share Zombies measures the asset-weighted share of zombie firms in a particular market at $t-1$. A firm is classified as zombie if it is low-quality and paid advantageous interest rates (see Section 4.2 for more details). Standard errors are clustered at the industry-country level and reported in parentheses. $* * * \mathrm{p}<0.01, * *$ $\mathrm{p}<0.05,{ }^{*} \mathrm{p}<0.1$

the cost inflation-price inflation relationship weakened as many countries experienced lower inflation since the nineties. A growing body of empirical literature documents this weakened link, mostly focusing on labor costs. In the US, Peneva and Rudd (2017) and Daly and Hobijn (2014) suggest that the recent relationship between wages and inflation is consistent with an improved anchoring of inflation expectations and downward wage rigidity in a period of low inflation, respectively. Bobeica et al. (2018) document this weakened relationship in Germany, France, Italy, and Spain.

In sum, consistent with the zombie credit channel, we find that markets that experience an increase in the share of zombie firms subsequently have lower entry and exit rates, a larger growth in the number of active firms, higher aggregate sales growth rates, higher average 


\begin{tabular}{lcccc} 
Panel A & Material Cost & Material Cost & Material Cost & Material Cost \\
\hline Share Zombies & $0.055^{* *}$ & $0.055^{* *}$ & $0.050^{* *}$ & $0.050^{* *}$ \\
& $(0.023)$ & $(0.023)$ & $(0.023)$ & $(0.024)$ \\
\hline Observations & 3,701 & 3,701 & 3,701 & 3,701 \\
R-squared & 0.943 & 0.951 & 0.945 & 0.953 \\
\hline & Labor Cost & Labor Cost & Labor Cost & Labor Cost \\
Panel B & 0.015 & 0.006 & 0.004 & -0.008 \\
\hline Share Zombie & $(0.022)$ & $(0.024)$ & $(0.024)$ & $(0.027)$ \\
& -0.002 & 0.003 & $-0.007^{*}$ & -0.003 \\
High Vacancy & $(0.004)$ & $(0.004)$ & $(0.004)$ & $(0.004)$ \\
& $0.095^{* * *}$ & $0.124^{* * *}$ & $0.110^{* *}$ & $0.138^{* * *}$ \\
Share Zombie & $(0.036)$ & $(0.043)$ & $(0.043)$ & $(0.052)$ \\
$\quad \times$ High Vacancy & 922 & 922 & 922 & 922 \\
\hline Observations & 0.259 & 0.360 & 0.397 & 0.500 \\
R-squared & & & & \\
\hline & & & & \\
Panel C & Productivity & Productivity & Productivity & Productivity \\
\hline Share Zombies & $-0.283^{* * *}$ & $-0.281^{* *}$ & $-0.259^{* *}$ & $-0.248^{*}$ \\
& $(0.103)$ & $(0.124)$ & $(0.105)$ & $(0.126)$ \\
\hline Observations & 3,811 & 3,811 & 3,811 & 3,811 \\
R-squared & 0.868 & 0.885 & 0.874 & 0.890 \\
\hline & & & & $\checkmark$ \\
\hline Country-Industry FE & $\checkmark$ & $\checkmark$ & $\checkmark$ & $\checkmark$ \\
Year FE & $\checkmark$ & $\checkmark$ & & $\checkmark$ \\
Industry-Year FE & & & & $\checkmark$ \\
Country-Year FE & & & & $\checkmark$ \\
\hline
\end{tabular}

Table 8: Input Costs and Productivity: Industry-Country Evidence. This table presents estimation results from specification (2). The dependent variables are the industry material cost (material input cost/turnover, Panel A), the industry labor cost (Eurostat's labor cost index, Panel B), and asset-weighted productivity $\left(\log (\right.$ sales $)-2 / 3^{*} \log \left(\right.$ employment) $-1 / 3^{*} \log ($ fixed assets), Panel C). Share Zombies measures the asset-weighted share of zombie firms in a particular market at $t-1$. A firm is classified as zombie if it is low-quality and paid advantageous interest rates (see Section 4.2 for more details). Standard errors are clustered at the industry-country level and reported in parentheses. ${ }^{* * *} \mathrm{p}<0.01,{ }^{* *} \mathrm{p}<0.05,{ }^{*} \mathrm{p}<0.1$

input costs, lower average productivity, lower average markups, and lower CPI growth.

The observed negative correlation, across markets, between the zombie share and inflation is also consistent with a cost channel (Barth III and Ramey, 2001) and a liquidity squeeze channel (Chevalier and Scharfstein, 1996). The cost channel suggests that the glut of cheap debt decreased the financial expenses of zombie firms, which gave them more wiggle room to cut output prices. The liquidity squeeze channel suggests that low-quality zombie firms have an incentive to raise prices to increase their current cash flows, while zombie firms do not have 
the necessity to react this way due to their access to cheap credit. However, the cost channel and the liquidity squeeze channel cannot explain the negative correlation between the zombie share and (i) firm default, (ii) firm entry rates, and (iii) firm productivity, nor the positive correlation with aggregate sales growth and input costs. Moreover, the cost channel cannot explain the negative correlation between between the zombie share and average markups. Hence, while these channels might have contributed to the dis-inflationary trend they are likely not the sole driver for the observed low inflation level in zombie markets.

The evidence presented in Table 8 suggests that the effect of the zombie credit channel on inflation likely constitutes a lower bound. In particular, since markets that experienced a zombie share increase have lower average productivity and higher average input costs, their production cost level is pushed upwards. Hence, without a change in markups, this costs push would increase prices. The observed inflation reduction for zombie industries thus implies that the excess production capacity induced the firms in these markets to lower markups to such an extent that it overcompensated the production costs increase.

\section{Firm-Level Analysis}

In this section, we take advantage of our detailed firm-level data to test a unique prediction of the zombie credit channel, namely the existence of spillover effects on non-zombie firms active in markets with high zombie prevalence.

According to the zombie credit channel, a rise of zombie credit leads to a higher number of active firms and excess productive capacity. This excessive productive capacity leads to a sales decrease for individual non-zombie firms as more firms have to share a given demand level. ${ }^{14}$ Non-zombie firms also face higher input prices due to an increased number of active firms that compete for a limited amount of resources.

In sum, for non-zombie firms in zombie markets, the zombie credit channel predicts lower

\footnotetext{
${ }^{14}$ Recall that, at the industry-country level, the zombie credit channel predicts a slight increase in aggregate sales for zombie industries due to the downward adjusted output prices and the resulting slightly higher aggregate demand. Table 6, Panel B confirms this prediction.
} 


\begin{tabular}{lcccc} 
& Markup & Sales Growth & Material Cost & EBIT/Sales \\
\hline Non-Zombie & $0.060^{* * *}$ & $0.061^{* * *}$ & $-0.022^{* * *}$ & $0.086^{* * *}$ \\
& $(0.006)$ & $(0.007)$ & $(0.002)$ & $(0.008)$ \\
Non-Zombie & $-0.226^{* * *}$ & $-0.176^{* * *}$ & $0.064^{* * *}$ & $-0.198^{* * *}$ \\
$\quad \times$ Industry Share Zombies & $(0.043)$ & $(0.034)$ & $(0.019)$ & $(0.033)$ \\
\hline Observations & $4,211,633$ & $5,922,959$ & $4,653,410$ & $5,910,165$ \\
R-squared & 0.584 & 0.032 & 0.521 & 0.151 \\
\hline Industry-Country-Year FE & $\checkmark$ & $\checkmark$ & $\checkmark$ & $\checkmark$ \\
Firm-Level Controls & $\checkmark$ & $\checkmark$ & $\checkmark$ & $\checkmark$ \\
\hline
\end{tabular}

Table 9: Markup, Sales Growth, Input Costs, EBIT/Sales: Firm-Level Evidence. This table presents estimation results from specification (3). The dependent variables are a firm's markup, sales growth, material cost (material input cost/turnover), or EBIT/Sales. Non-Zombie is an indicator variable equal to one if a firm is classified as non-zombie in year $t$. Industry Share Zombies measures the asset weighted share of zombie firms in an industry-country-year. Firm-level controls include net worth, leverage, the natural logarithm of total assets, and the interest coverage ratio. A firm is classified as zombie if it is low-quality and paid advantageous interest rates (see Section 4.2 for more details). Standard errors are clustered at the industry-country level and reported in parentheses. ${ }^{* * *} \mathrm{p}<0.01,{ }^{* *} \mathrm{p}<0.05,{ }^{*} \mathrm{p}<0.1$.

sales growth, lower markups, and higher input costs compared with individual non-zombie firms in non-zombie markets. Following Caballero et al. (2008), we test this prediction by estimating the following regression at the firm-year level:

$$
\begin{aligned}
Y_{i h j t} & =\beta_{1} \times \text { Non }- \text { Zombie }_{i h j t}+\beta_{2} \times \text { Non }- \text { Zombie }_{i h j t} \times \text { ShareZombies }_{h j t-1} \\
& +\gamma_{h j t}+\epsilon_{i h j t},
\end{aligned}
$$

where $i$ is a firm, $h$ is a country, $j$ is a industry, and $t$ is a year. Our dependent variables are firm markup, sales growth, material cost, and EBIT/Sales. We include industry-countryyear fixed effects to absorb country-industry specific shocks. Our coefficient of interest is $\beta_{2}$, that is, whether non-zombie firms that operate in markets with a high share of zombie firms perform differently than non-zombie firms in markets with a lower share of zombie firms.

The first column of Table 9 shows that non-zombie firms in markets with a low zombie prevalence have higher markups than zombie firms in the same market. However, consistent with our results at the industry-country level, markups of non-zombie firms tend to be lower the higher the share of zombie firms active in the same market. In the second column of the table, we also find a lower sales growth for individual non-zombie firms active in a market with a large zombie share increase. The results in the third column confirm that non-zombie firms that have to compete against a higher number of zombie firms (relative to non-zombie 
firms in non-zombie industries) indeed pay higher material costs. ${ }^{15}$

Finally, the results in the last column Table 9 suggests that there might be a zombie contagion from zombie to non-zombie firms in markets with a strong rise in zombie credit. That is, good firms in zombie markets not only suffer because they have lower individual sales growth due to the higher number of firms, but also because their profitability drops due to the excess capacity-induced fiercer competition in these markets. As a result, initially good non-zombie firms can turn into zombies over time due to a high prevalence of other zombies in their markets.

\section{Robustness}

This section provides several robustness tests. In Section 7.1, we use alternative zombie firm classifications. In Section 7.2, we redo our default rate tests employing a different data set. In Section 7.3, we conduct a placebo test for our firm-level analysis.

\subsection{Alternative Zombie Classifications}

To ensure the robustness of our results with respect to the zombie classification, we use various alternative zombie definitions and redo our analysis from Table 2.

First, we calculate median values for leverage and the interest coverage ratio at the industry-year level instead of the industry-country-year level. Second, we consider solely the interest coverage ratio criterion instead of both the interest coverage ratio and leverage to define a firm as low-quality. Third, we use solely the leverage criterion to define a firm as low-quality. Figure 9 shows that these alternative classifications yield a similar timeseries pattern for the (increasing) share of zombie firms. Table 10 shows that our results on the effect of a rise in zombie credit on inflation are robust to using alternative zombie classifications.

\footnotetext{
${ }^{15}$ We only observe a very noisy measure of labor costs at the firm level.
} 


\begin{tabular}{lcccc} 
Panel A & $\Delta$ CPI & $\Delta$ CPI & $\Delta$ CPI & $\Delta$ CPI \\
\hline Share Zombies (Alt. Def. \#1) & $-0.009^{*}$ & $-0.007^{*}$ & $-0.012^{* *}$ & $-0.011^{* * *}$ \\
& $(0.005)$ & $(0.004)$ & $(0.005)$ & $(0.004)$ \\
\hline Observations & 3,880 & 3,880 & 3,880 & 3,880 \\
R-squared & 0.491 & 0.723 & 0.521 & 0.754 \\
\hline & & & & \\
Panel B & $\Delta$ CPI & $\Delta$ CPI & $\Delta$ CPI & $\Delta$ CPI \\
\hline Share Zombies (Alt. Def. \#2) & $-0.010^{* *}$ & $-0.008^{* *}$ & $-0.013^{* * *}$ & $-0.010^{* * *}$ \\
& $(0.005)$ & $(0.004)$ & $(0.005)$ & $(0.004)$ \\
\hline Observations & 3,880 & 3,880 & 3,880 & 3,880 \\
R-squared & 0.491 & 0.723 & 0.521 & 0.754 \\
\hline & & & & \\
Panel C & $\Delta$ CPI & $\Delta$ CPI & $\Delta$ CPI & $\Delta$ CPI \\
\hline Share Zombies (Alt. Def. \#3) & $-0.009^{* *}$ & $-0.007^{* *}$ & $-0.012^{* *}$ & $-0.010^{* * *}$ \\
& $(0.005)$ & $(0.004)$ & $(0.005)$ & $(0.004)$ \\
\hline Observations & 3,880 & 3,880 & 3,880 & 3,880 \\
R-squared & 0.491 & 0.723 & 0.521 & 0.754 \\
\hline Country-Industry FE & $\checkmark$ & $\checkmark$ & $\checkmark$ & $\checkmark$ \\
Year FE & $\checkmark$ & & & \\
Industry-Year FE & & $\checkmark$ & & $\checkmark$ \\
Country-Year FE & & & $\checkmark$ & $\checkmark$ \\
\hline
\end{tabular}

Table 10: Inflation: Industry-Country Evidence under Alternative Zombie Classifications. This table presents estimation results from specification (2). The dependent variable is the annual CPI growth rate (inflation) from $t$ to $t+1$. Share Zombies measures the asset-weighted share of zombie firms in a particular market at $t$. A firm is classified as zombie if it is low-quality and paid advantageous interest rates (see Section 4.2 for more details. Panel A calculates median values for leverage and interest coverage ratio at industry-year-level (instead of industry-country-year level). Panel B considers solely the interest coverage ratio criterion to define a firm as low-quality. Panel $\mathrm{C}$ considers only the leverage criterion to define a firm as low-quality. Standard errors are clustered at the industry-country level and reported in parentheses. *** $\mathrm{p}<0.01,{ }^{* *} \mathrm{p}<0.05,{ }^{*} \mathrm{p}<0.1$.

\subsection{Alternative Default Rate Measure}

The Eurostat data used in Table 7 to analyse the effect on an increase in the share of zombie firms on exit rates does not distinguish between different types of exit (i.e., insolvency or dissolved for other reasons).

Hence, as a robustness check, we redo this analysis using the legal status variable from Amadeus. In particular, to identify default events for our sample firms we flag firms that 


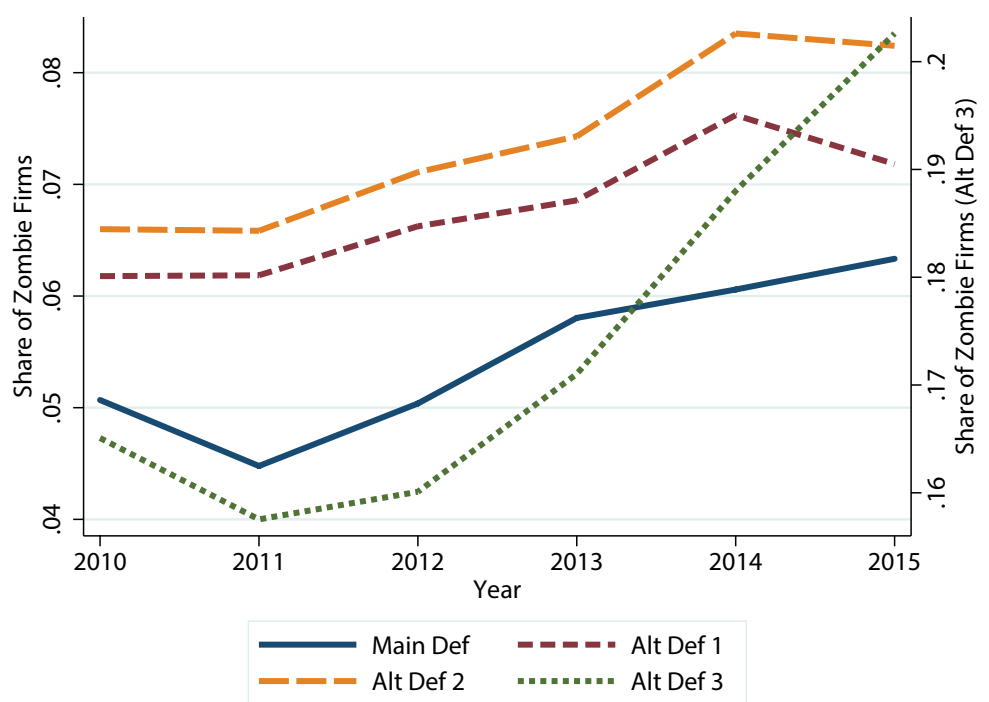

Figure 9: Alternative Zombie Definitions. This figure shows the evolution of the share of zombie firms for alternative zombie definitions. The blue solid line replicates our main measure of the share of zombie firms. Alt Def 1 (red dashed line) calculates median values for leverage and interest coverage ratio at the industry-year-level (instead of industry-country-year level). Alt Def 2 (orange dashed line) considers solely the interest coverage ratio criterion to define a firm as low-quality. Alt Def 3 (green dotted line) considers only the leverage criterion to define a firm as low-quality.

according to the legal status variable are in distress, insolvent, or bankrupt. ${ }^{16}$ In Table 11 , we show that we obtain similar results on the effect of a rise of zombie credit on firm defaults if we rely on the Amadeus default data.

\subsection{Firm-Level Robustness}

Finally, we conduct a placebo test for the firm level results presented in Section 5. In particular, instead of employing the share of zombie firms as the main variable of interest, we use the share of low-quality firms; thus, muting the advantageous interest rate criterion.

The results presented in Table 12 show that the spillover effects on non-zombie firms do not occur per se when the share of low-quality firms increases in a market. This evidence suggests that the contagion to non-zombie firms is indeed caused by an increase in the share

\footnotetext{
${ }^{16}$ That is, we identify firms that have one of the following legal status in Amadeus: "Active (default of payments)", "Active (insolvency proceedings)", "Active (rescue plan)", "Bankruptcy", "Dissolved (bankruptcy)", "Dissolved (liquidation)", or "In liquidation".
} 


\begin{tabular}{lcccc} 
& Default & Default & Default & Default \\
\hline Share Zombies & $-0.013^{*}$ & $-0.015^{* *}$ & $-0.016^{* *}$ & $-0.018^{* *}$ \\
& $(0.008)$ & $(0.007)$ & $(0.008)$ & $(0.007)$ \\
\hline Observations & 2,708 & 2,708 & 2,708 & 2,708 \\
R-squared & 0.843 & 0.862 & 0.886 & 0.906 \\
\hline Country-Industry FE & $\checkmark$ & $\checkmark$ & $\checkmark$ & $\checkmark$ \\
Year FE & $\checkmark$ & & & \\
Industry-Year FE & & $\checkmark$ & & $\checkmark$ \\
Country-Year FE & & & $\checkmark$ & $\checkmark$
\end{tabular}

Table 11: Firm Defaults: Industry-Country Evidence based on Amadeus Data. This table presents estimation results from specification (2). The dependent variable is the share of firm defaults at time $t$. Share Zombies measures the asset-weighted share of zombie firms in a particular market at $t-1$. A firm is classified as zombie if it is low-quality and paid advantageous interest rates (see Section 4.2 for more details). Standard errors are clustered at the industry-country level and reported in parentheses. $* * *$ $\mathrm{p}<0.01,{ }^{* *} \mathrm{p}<0.05,{ }^{*} \mathrm{p}<0.1$

of actual zombie firms, that is, low-quality firms receiving subsidized credit.

Moreover, these results provide further evidence that the negative correlation between the rise of zombie credit and inflation is not linked per se to a deteriorating average firm performance in a specific market (e.g., due to a drop in demand). These impaired firms need to have been kept alive by readily available cheap credit, inducing a drop in default rates, to cause downward pressure on inflation.

\section{Conclusion}

The low-growth low-inflation environment that prevails in Europe after its sovereign debt crisis bears a striking resemblance to Japan's "lost decades" in the aftermath of its crisis in the early 1990s. Similar to the Bank of Japan's crisis response, the European central banks followed canonical demand-side theory and lowered interest rates, as well as, implemented massive quantitative easing programs to encourage more investment and consumption, hoping that this will lead to a surge in inflation. However, despite a significant drop in firm funding costs, inflation did not pick up as expected, which became known as Europe's "missing inflation puzzle" (see, e.g., Constâncio, 2015).

In this paper, we propose a novel supply-side channel that shows that policy measures that make cheap debt financing readily available to impaired firms have a disinflationary side effect, thereby providing an explanation for the persistent low inflation rates in Europe. 


\begin{tabular}{lcccc} 
& Markup & Sales Growth & Material Cost & EBIT/Sales \\
\hline Non-Zombie & $0.040^{* * *}$ & $0.037^{* * *}$ & $-0.017^{* * *}$ & $0.065^{* * *}$ \\
& $(0.010)$ & $(0.006)$ & $(0.004)$ & $(0.006)$ \\
Non-Zombie & 0.017 & 0.037 & -0.002 & 0.022 \\
$\quad \times$ Industry Share Low-Quality & $(0.038)$ & $(0.024)$ & $(0.009)$ & $(0.033)$ \\
\hline Observations & $4,211,633$ & $5,922,959$ & $4,653,410$ & $5,910,165$ \\
R-squared & 0.565 & 0.033 & 0.5128 & 0.157 \\
\hline Industry-Country-Year FE & $\checkmark$ & $\checkmark$ & $\checkmark$ & $\checkmark$ \\
Firm-Level Controls & $\checkmark$ & $\checkmark$ & $\checkmark$ & $\checkmark$ \\
\hline
\end{tabular}

Table 12: Firm-Level Analysis, Robustness. This table presents estimation results from specification (3). The dependent variables are a firm's markup, sales growth, material cost (material input cost/turnover), or EBIT/Sales. Non-Zombie is an indicator variable equal to one if a firm is classified as non-zombie in year t. Industry Share Low-Quality measures the asset weighted share of low-quality firms in an industry-countryyear. Firm-level controls include net worth, leverage, the natural logarithm of total assets, and the interest coverage ratio. A firm is classified as low-quality if it has a below median interest coverage ratio and an above median leverage. Standard errors are clustered at the industry-country level and reported in parentheses. $* * * \mathrm{p}<0.01,{ }^{* *} \mathrm{p}<0.05,{ }^{*} \mathrm{p}<0.1$.

Accommodative policy measures reduce financial pressure and thereby fuel the survival of weak firms with unsustainable business models. As these zombie firms proliferate, aggregate supply increases compared to the case where the business cycle runs its normal course. The resulting excess capacity puts downward pressure on producer prices, and, ultimately, depresses inflation levels.

We test this zombie credit channel using a new inflation and firm level data set that covers 1.1 million firms in 12 European countries across 65 industries. We show that industries that experienced a stronger rise of zombie firms subsequently experienced fewer firm defaults, lower average firm markups, product prices, and productivity, an increase in aggregate sales, as well as, material and labor costs, and a lower inflation level.

These results draw attention to the often-neglected impact of supply-side financial frictions on inflation. Specifically, our findings highlight that while monetary and macroprudential policies are important to achieve macroeconomic and financial stability, closely monitoring their interaction with financial frictions at the micro-level and teasing out their precise transmission to the real economy are equally important. Otherwise, financial frictions can lead to unintended macroeconomic consequences of accommodative policies and work precisely against the policies' stated and assumed objectives of generating inflation and growth.

For accommodative monetary policy to be effective in times of a weakening financial sector, it should thus be accompanied by a targeted financial sector recapitalization program. 
A prime example for such a targeted recapitalisation was in the United States (US), where the Troubled Asset Relief Program (TARP) and the effective stress test of banks in the form of Supervisory Capital Assessment Program (SCAP) followed the failure of Lehman Brothers and coincided with the extraordinary easing of monetary policy by the Federal Reserve. The targeted recapitalization of the financial sector contributed to a faster recovery of the US economy. Indeed, after a brief deflationary period, the US inflation rate climbed back to around $2 \%$ in early 2010. Conversely, except for a few brief periods, the inflation rate in Japan has been close to zero since the mid-1990s. Similarly, the euro area inflation rate has been declining since the start of the loose monetary policy in 2012 and has remained below $1 \%$ in the period from 2014 to 2017.

Moreover, our results suggest that, at least for European countries that still have free sovereign debt capacity, a more expansive fiscal policy could potentially be an effective tool to raise inflation, since the resulting positive demand shock would absorb at least part of the zombie-induced excess capacity. Studying such interactions of fiscal and monetary policy tools is an important area for future research.

\section{References}

Acharya, V. V., T. Eisert, C. Eufinger, And C. Hirsch (2019): "Whatever It Takes: The Real Effects of Unconventional Monetary Policy," The Review of Financial Studies, $32,3366-3411$.

AckerberG, D., K. Caves, And G. Frazer (2006): "Structural identification of production functions," .

Adalet McGowan, M., D. Andrews, And V. Millot (2018): "The walking Dead? Zombie Firms and Productivity Performance in OECD Countries," Economic Policy, 33, $685-736$.

Aghion, P., E. Farhi, And E. Kharroubi (2018): "Monetary Policy, Product Market Competition, and Growth," .

Banerjee, R. And B. Hofmann (2018): "The rise of zombie firms: causes and consequences," Working Paper.

BARth III, M. J. AND V. A. RAmey (2001): "The cost channel of monetary transmission," NBER macroeconomics annual, 16, 199-240. 
Blattner, L., L. Farinha, and F. Rebelo (2019): "When Losses Turn Into Loans: The Cost of Undercapitalized Banks," Working Paper.

Bobeica, E., M. Ciccarelli, And I. Vansteenkiste (2018): "The Link Between Labor Cost and Price Inflation in the Euro Area," ECB Working Paper.

Borio, C. E. And B. Hofmann (2017): "Is monetary policy less effective when interest rates are persistently low?" Working Paper.

Caballero, R. J., T. Hoshi, and A. K. Kashyap (2008): "Zombie Lending and Depressed Restructuring in Japan," American Economic Review, 98, 1943-77.

Campbell, J. R. and H. A. Hopenhayn (2005): "Market size matters," The Journal of Industrial Economics, 53, 1-25.

Chevalier, J. A. And D. S. Scharfstein (1996): "Capital-Market Imperfections and Countercyclical Markups: Theory and Evidence," The American Economic Review, 703725 .

Christiano, L. J., M. S. Eichenbaum, and M. Trabandt (2015): "Understanding the great recession," American Economic Journal: Macroeconomics, 7, 110-67.

ConstÂncIo, V. (2015): "Understanding Inflation Dynamics and Monetary Policy," in Speech at the Jackson Hole Economic Policy Symposium, vol. 29.

Daly, M. and B. HobiJn (2014): "Downward Nominal Wage Rigidities Bend the Phillips Curve," Journal of Money, Credit, and Banking, 46, 51-93.

DE Almeida, L. A. (2015): "Firms' balance sheets and sectoral inflation in the Euro area during the financial crisis," Economics Letters, 135, 31-33.

De Loecker, J. And J. Eeckhout (2019): "The rise of market power and the macroeconomic implications," Working Paper.

De Loecker, J. And F. Warzynski (2012): "Markups and firm-level export status," American economic review, 102, 2437-71.

Del Negro, M., M. Lenza, G. Primiceri, and A. Tambalotti (2020): "What's up with the Philipps Curve," Working Paper.

Giannetti, M. And A. Simonov (2013): "On the real effects of bank bailouts: Micro evidence from Japan," American Economic Journal: Macroeconomics, 5, 135-67.

Gilchrist, S., R. Schoenle, J. Sim, and E. Zakrajšek (2017): "Inflation dynamics during the financial crisis," American Economic Review, 107, 785-823.

Kalemli-Ozcan, S., B. Sorensen, C. Villegas-Sanchez, V. Volosovych, and S. YesiLtas (2015): "How to construct nationally representative firm level data from the ORBIS global database," . 
Levinsohn, J. And A. Petrin (2003): "Estimating production functions using inputs to control for unobservables," The Review of Economic Studies, 70, 317-341.

Lewis, V. AND C. Poilly (2012): "Firm entry, markups and the monetary transmission mechanism," Journal of Monetary Economics, 59, 670-685.

Lewis, V. And A. Stevens (2015): "Entry and markup dynamics in an estimated business cycle model," European Economic Review, 74, 14-35.

Olley, G. S. And A. Pakes (1996): "The Dynamics of Productivity in the Telecommunications Equipment Industry," Econometrica: Journal of the Econometric Society, $1263-1297$.

Paravisini, D., V. Rappoport, P. Schnabl, and D. Wolfenzon (2015): "Dissecting the Effect of Credit Supply on Trade: Evidence from matched Credit-Export Data," The Review of Economic Studies, 82, 333-359.

Peek, J. And E. Rosengren (2005): "Unnatural Selection : Perverse Incentives and the Misallocation of Credit in Japan," American Economic Review, 95, 1144-1166.

Peneva, E. And J. Rudd (2017): "Low Inflation, Pass-Through, and the Pricing Power of Firms," Journal of Money, Credit, and Banking, 49, 1777-1802.

Schivardi, F., E. Sette, And G. Tabellini (2017): "Credit Misallocation During the European Financial Crisis," Working Paper.

TAYlor, J. (2000): "Low Inflation, Pass-Through, and the Pricing Power of Firms," European Economic Review, 44, 1389-1408. 


\section{Appendix A Model}

In this appendix, we develop a simple dynamic model to analyze the relationship between zombie credit and inflation. We define an equilibrium with and without zombie credit and then compare equilibrium quantities and prices. The model adds imperfect competition among firms to a framework similar to Caballero et al. (2008). The reader is referred to the online appendix for formal derivations and proofs.

\section{A.1 Setup}

Time is discrete and the economy is populated by a large, but finite number of firms that produce a single good. Firms are identical in size and can be incumbent or potential entrants. At each date $t$, there are $m_{t}$ incumbent firms and $e$ potential entrant firms.

The problem of firms at each date $t$ is as follows. First, firms (incumbents and potential entrants) pay a cost $I$ to set up their capacity that allows them to draw their production $y_{i t}$ from a uniform distribution $y_{i t} \sim U[0,1]$. Second, incumbent firms simultaneously set prices. Third, firms learn the realization of their production $y_{i t}$ leading to profits $\left(p_{t}-c\right) y_{i t}-I$, where $c$ is the marginal cost. Depending on the realization of their production, potential entrant firms might enter the market and incumbent firms might default. A firm that makes negative profits is forced to default.

There is an exogenous demand $D_{t}\left(p_{t}\right)=\alpha_{t}-p_{t}$, where $p_{t}$ is the average price set by incumbent firms. This aggregate demand is satiated starting with the production of the firm that sets the lowest price. ${ }^{17}$

Lemma 1. Firms choose $p_{i t}=p_{t}$, where

$$
p_{t}=\alpha_{t}-\frac{m_{t}}{2}
$$

\footnotetext{
${ }^{17}$ Given $p_{t}=\sum_{i} p_{i t} / m_{i t}$, this allocation rule resembles a limit order book used in stock exchanges. If multiple firms set the same lowest price, the demand is split evenly among them.
} 
Proof. Suppose $m_{t}$ identical firms set prices simultaneously at $t$ before the realization of the production parameter in a single shot game. The marginal cost of production is $c$. There is only one good and the demand is $D\left(p_{t}\right)=\alpha_{t}-p_{t}$, where $\alpha_{t} \geq \frac{1}{2}\left(m_{t}+1\right)+c$. The expected production is $\mathbb{E}\left(y_{i t}\right)=\frac{1}{2}$. This problem is similar to a Bertrand price-setting model with an exogenous capacity constraint equal to the expected production. We claim that $p_{i t}=p_{t}^{*}=\alpha_{t}-\frac{m_{t}}{2}$. Given the one shot nature of the game, we can ignore the time subscripts. Firm $i$ optimally deviates from $p_{i}=p_{-i}<p^{*}$ because it can get a higher price on the residual demand given that other firms cannot produce more than $\frac{1}{2}$ in expectation. Firm $i$ optimally deviates from $p_{i}=p_{-i}>p^{*}$ because it can undercut slightly the price and expect to sell its entire expected production. Firm $i$ optimally deviates from $p_{i}<p_{-i}$ because it can get a higher price on the residual demand.

Firms set prices knowing that their expected production is $1 / 2$. In the unique equilibrium, the price $p_{t}$ set by incumbents firms is such that the total expected production equals demand at the price $p_{t}$. It is not optimal for firm $i$ to lower its price as it will end up selling at a lower price its entire expected production. It is also not optimal for firm $i$ to increase its price as it can increase profit by increasing the expected quantity sold. ${ }^{18}$ Because of the production constraint, firms charge a positive markup $\left(p_{t}-c\right) / c{ }^{19}$

After the price is set, firms learn the realization of their production. An incumbent firm that generates negative profits is forced to default. Hence, the mass of defaulting firms $D_{t}$ and the mass of surviving incumbent firms $S_{t}$ are:

$$
D_{t}=m_{t} \int_{0}^{\frac{I}{p_{t}-c}} d i=\frac{m_{t} I}{p_{t}-c} \quad S_{t}=m_{t} \int_{\frac{I}{p_{t}-c}}^{1} d i=m_{t}\left(1-\frac{I}{p_{t}-c}\right) .
$$

A potential entrant firm that generates profits enters the market. The mass of entrants is:

$$
E_{t}=e \int_{\frac{I}{p_{t}-c}}^{1} d i=e\left(1-\frac{I}{p_{t}-c}\right)
$$

\footnotetext{
${ }^{18}$ If $\alpha_{t}$ is large enough, the marginal revenue is greater than the marginal cost, that is, the firm can increase its profit by lowering the price and, in turn, increasing the quantity produced.

${ }^{19}$ The price $p_{t}$ is determined in terms of cost as the numeraire. In our environment, we implicitly assume a form of rigidity on the cost side.
} 
Total production $N_{t}$ is the sum of the production of entrants and surviving incumbents:

$$
N_{t}=\left(e+m_{t}\right)\left(1-\frac{I}{p_{t}-c}\right) .
$$

\section{A.2 Equilibrium}

In this section, we define an equilibrium with and an equilibrium without zombie credit.

Definition 1. Given the demand parameter $\alpha$, setup cost I, marginal cost $c$, an equilibrium without zombie credit ( $E q N$ ) is price $p_{t}$, incumbents $m_{t}$, production $N_{t}$ such that the product price is given by Eq. (A1), total production equals the sum of production by surviving incumbent and entrant firms according to Eq. (A2), and the number of incumbent follows $m_{t+1}=N_{t}$.

The equilibrium without zombie credit $(\mathrm{EqN})$ is governed by three conditions. First, the price of the good follows Lemma 1. Second, total production is the sum of the production of firms that enter the market and production of incumbent firms that survive. Third, the incumbent firms at $t+1$ are the sum of entrants and surviving incumbent firms at $t$.

In the steady state equilibrium, the number of incumbent firms is constant $\left(m_{t+1}=N_{t}=\right.$ $m)$ and defaults are exactly offset by entry:

$$
\frac{m I}{p-c}=e\left(1-\frac{I}{p-c}\right)
$$

The equilibrium with zombie credit (EqZ) is characterized by an exogenous number of firms $\bar{S}$ that survive each period, leading to a total production of

$$
N_{t}=e\left(1-\frac{I}{p_{t}-c}\right)+\bar{S}
$$

Following Caballero et al. (2008), the idea is that favourable funding conditions might keep some firms alive that otherwise would default. Formally, the definition of EqZ is as follows:

Definition 2. Given the demand parameter $\alpha$, setup cost I, marginal cost $c$, and survivors $\bar{S}$, an equilibrium with zombie credit $(E q Z)$ is price $p_{t}$, incumbents $m_{t}$, production $N_{t}$ such 
that the product price is given by Eq. (A1), total production equals the sum of production by surviving incumbent and entrant firms according to Eq. (A3), defaults are such that surviving firms are $\bar{S}$, and the number of incumbent follow $m_{t+1}=N_{t}$.

The equilibrium with zombie credit is characterized by four conditions. First, the price of the good follows Lemma 1. Second, total production is the sum of the production of firms that enter the market and production of the, now exogenously set, incumbent firms that survive. Third, defaults are such that surviving firms are constant at $\bar{S}$. Fourth, the incumbent firms at $t+1$ are the sum of entrants and surviving incumbent firms at $t$.

\section{A.3 Macroeconomic Effects of Zombie Credit}

We analyze the effects of zombie credit by comparing the equilibrium without zombie credit and the equilibrium with zombie credit following a negative demand shock, captured by a permanent decrease in $\alpha .{ }^{20}$ More specifically, we consider the case where EqN and EqZ are, before the shock, identical in a steady state equilibrium (the number of survivors $\bar{S}$ in EqZ is set equal to the number of survivors in EqN). Figure A.1 shows this comparison, where the solid lines correspond to EqN and the dashed lines correspond to EqZ. In both equilibrium concepts, the negative demand shock causes a contemporaneous collapse in prices. The adjustment to the new steady state depends on the type of equilibrium.

In EqN, the collapse in price leads to a contemporaneous decrease in entries and increase in defaults. One period after the shock, the lower number of active firms causes the price to rebound (higher productive capacity), which induces more firms to enter the market and fewer incumbent firms to default. Two periods after the shock, the now higher number of incumbent firms leads to a reduction in price and, in turn, an increase in defaults and a decrease in entries. This adjustment continues until the economy reaches the new EqN steady state where the price, defaults, and entry are lower and there are fewer incumbent

\footnotetext{
${ }^{20}$ In Figure A.2, we show that the intuition of the model holds when we compare the equilibrium without zombie credit and the equilibrium with zombie credit following a temporary demand shock.
} 

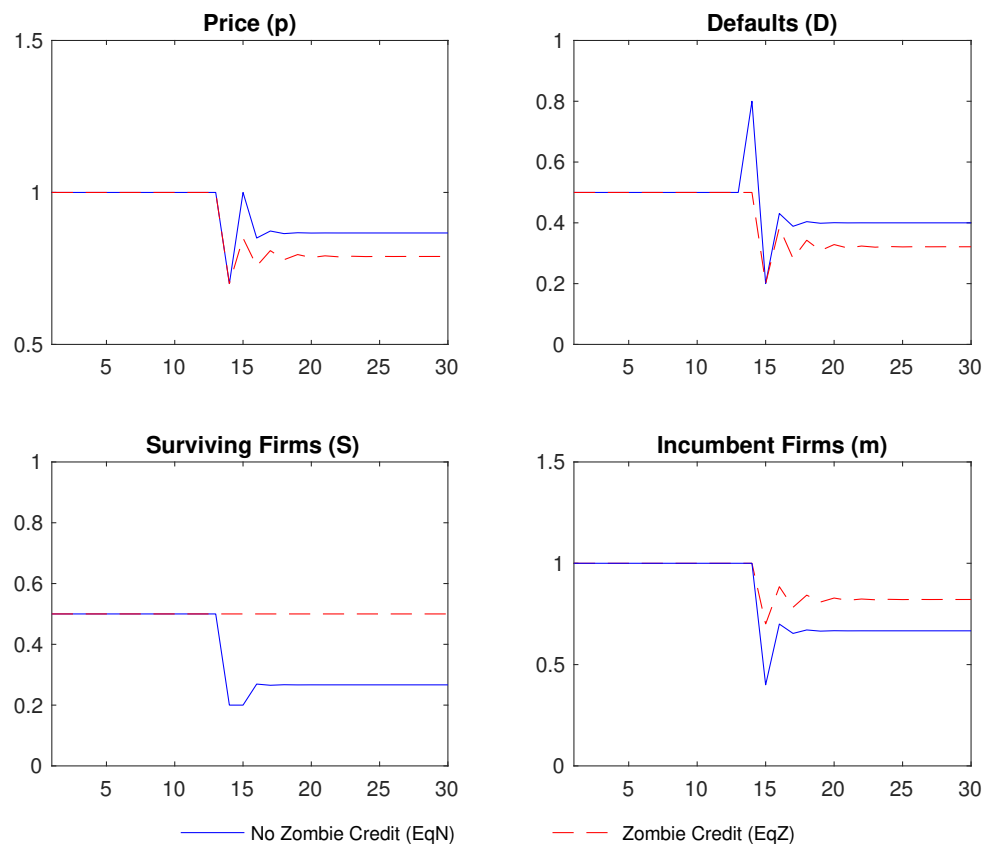

Figure A.1: Negative Demand Shock. This figure shows how equilibrium quantities and prices respond to a permanent decrease in $\alpha$ in EqN (solid lines) and in EqZ (dashed lines).

firms compared with the pre-shock steady state.

In EqZ, the collapse in price also induces a contemporaneous decrease in entries but defaults are held constant so as to keep the number of surviving firms also constant. This lack of adjustment through defaults causes the number of incumbent firms to go down less than in EqN one period after the shock. The price rebound also leads to an increase in entries, but this adjustment is muted compared to EqN. The lower number of incumbent firms causes a reduction in defaults in order to keep the number of survivors constant. Two periods after the shock, the number of incumbent firms is lower than in the previous period but higher than in EqN. This adjustment continues until the economy reaches the new steady state. Compared with the EqN steady state, the price, entry, and defaults are lower and there are more incumbent firms. More formally:

Proposition 1. In the equilibrium with zombie credit, in steady state, fewer firms default, there are more incumbent firms, the price and markup are lower, and fewer firms enter compared with the steady state in an equilibrium with no zombie credit.

Proof. The steady state conditions in EqN are $p=\alpha-\frac{m}{2}$ and $\frac{m I}{p-c}=e\left(1-\frac{I}{p-c}\right)$. By combining them, we 
obtain:

$$
m=\frac{e(\alpha-c-I)}{I+\frac{e}{2}} \quad \text { and } \quad p=\frac{2 \alpha I+e(c+I)}{2 I+e}
$$

The steady state conditions in EqZ are $\widetilde{p}=\alpha-\frac{1}{2} \widetilde{m}, \widetilde{m}=e\left(1-\frac{I}{p-c}\right)+\bar{S}$, and $\widetilde{D}=\widetilde{m}-\bar{S}$. Suppose that $\bar{S}$ is such that the EqN and EqZ equilibria are identical, namely

$$
\bar{S}=\frac{2 e(\alpha-c-I)^{2}}{(I+e / 2)(2 \alpha+e-2 c)}
$$

Suppose $\alpha^{\prime}<\alpha$. Combining the steady state conditions, we obtain a contradiction if $\widetilde{p}\left(\alpha^{\prime}\right) \geq p\left(\alpha^{\prime}\right)$. From $\widetilde{p}\left(\alpha^{\prime}\right) \geq p\left(\alpha^{\prime}\right)$, it follows that $S \leq m\left(\alpha^{\prime}\right)\left(1-\frac{I}{p\left(\alpha^{\prime}\right)-c}\right)$. But it is easy to show that $S>m\left(\alpha^{\prime}\right)\left(1-\frac{I}{p\left(\alpha^{\prime}\right)-c}\right)$. Hence, the contradiction. It follows that $m\left(\alpha^{\prime}\right)<\widetilde{m}\left(\alpha^{\prime}\right)$ and $p\left(\alpha^{\prime}\right)>\widetilde{p}\left(\alpha^{\prime}\right)$. It also trivially follows that entry, defaults, and markups are lower in EqZ compared with EqN.

In the equilibrium with zombie credit, some firms that would default in the equilibrium without zombie credit are kept alive preventing a downward adjustment in the number of active firms and, in turn, causing a reduction in price. Let $p(\alpha, E(\alpha), S(\alpha))$ be the steady state price, expressed as a function of $\alpha$. Note that the price functions are different in EqN and EqZ. Differentiating with respect to $\alpha$ yields:

$$
\frac{d p}{d \alpha}=\frac{\partial p}{\partial \alpha}+\frac{\partial p}{\partial E} \frac{\partial E}{\partial \alpha}+\underbrace{\frac{\partial p}{\partial S} \frac{\partial S}{\partial \alpha}}_{=0 \text { in EqZ }}
$$

Demand affects the price in three ways. First, the direct effect: a lower demand reduces the price in equilibrium. Second, a lower demand reduces firm entry, causing an increase in price. Third, a lower demand induces more firms to default, which leads to an increase in price. This third effect disappears in EqZ, where the number of surviving firms is not affected by the change in demand.

\section{A.4 Effect on Input Costs}

In a variation of the baseline model, we show in this section that input costs are higher in the equilibrium with zombie credit compared with the equilibrium without zombie credit.

The differences with the baseline model environment are as follows. First, the product price is now exogenous. Second, there is an exogenous supply of input $L_{t}=c_{t}-\mu_{t}$, where 

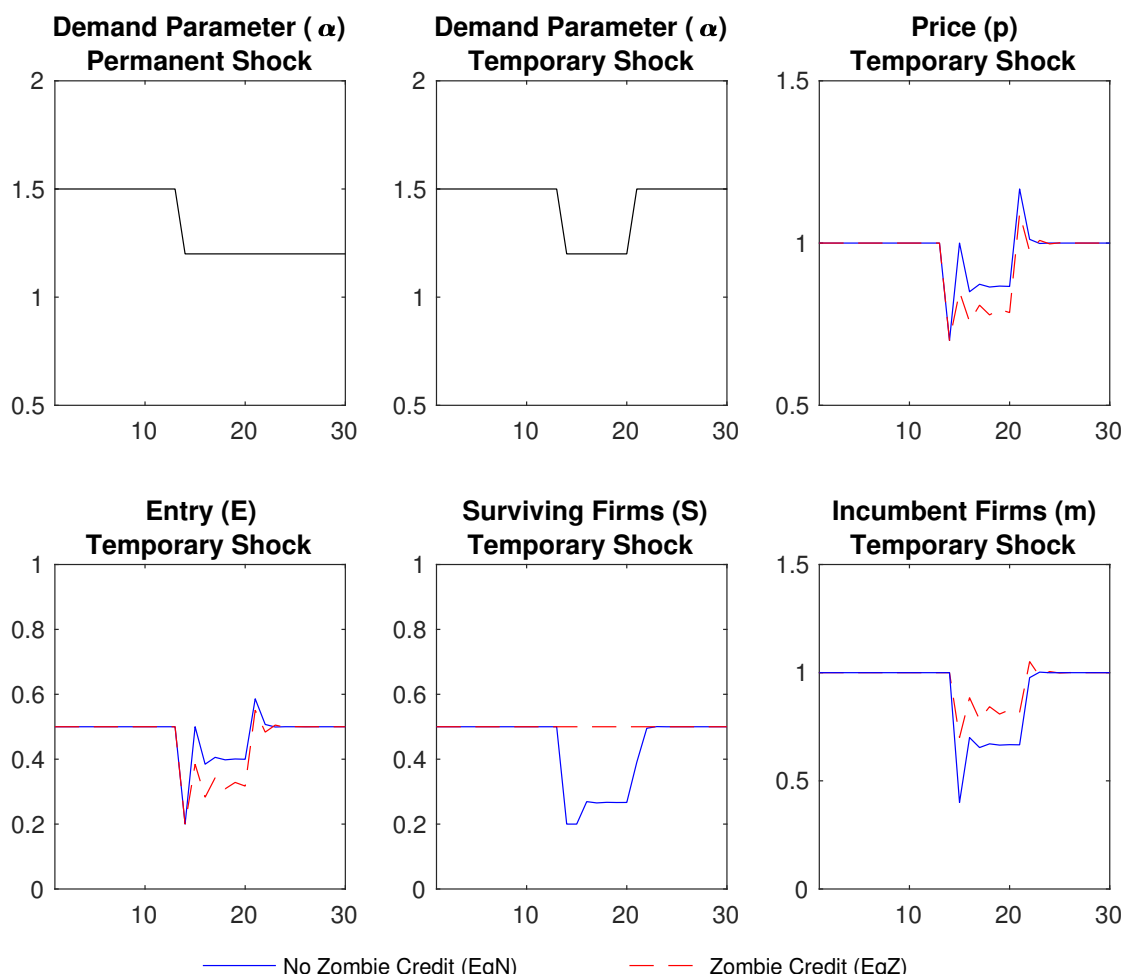

Figure A.2: Temporary Negative Demand Shock. This figure shows how equilibrium quantities and prices respond to a temporary decrease in $\alpha$ in EqN (solid lines) and in EqZ (dashed lines).

$c_{t}$ is the price of input and marginal cost for each firm $i$. Third, after paying the setup cost $I$, firms set the price $c_{t}$ of the input, knowing that their expected production is $1 / 2$. In this environment, the two equilibrium definitions take the product price as given and display the equilibrium condition for the input cost: $c_{t}=\frac{m_{t}}{2}+\mu_{t}$. The intuition for this expression follows the intuition from Lemma 1. Firms set the marginal cost of input $c_{t}$ such that the total demand for the input equals its supply at the price $c_{t}$.

Similar to Section A.3, we can analyze the effect of a permanent decrease in the (now exogenous) product price on the (now endogenous) marginal cost. In the equilibrium without zombie credit, the negative demand shock reduces total production as the lower price reduces entry and increases exit. In the next period, the lower number of incumbent firms reduces the input price, causing an increase in entry and a decrease in exit. The resulting production increase causes a rebound in the number of incumbent firms in the next period. This adjustment continues until the economy reaches the new steady state with a lower number of active firms and lower input costs. Again, this adjustment is muted in the equilibrium with zombie credit. 


\section{Appendix B Inflation - Additional Robustness}

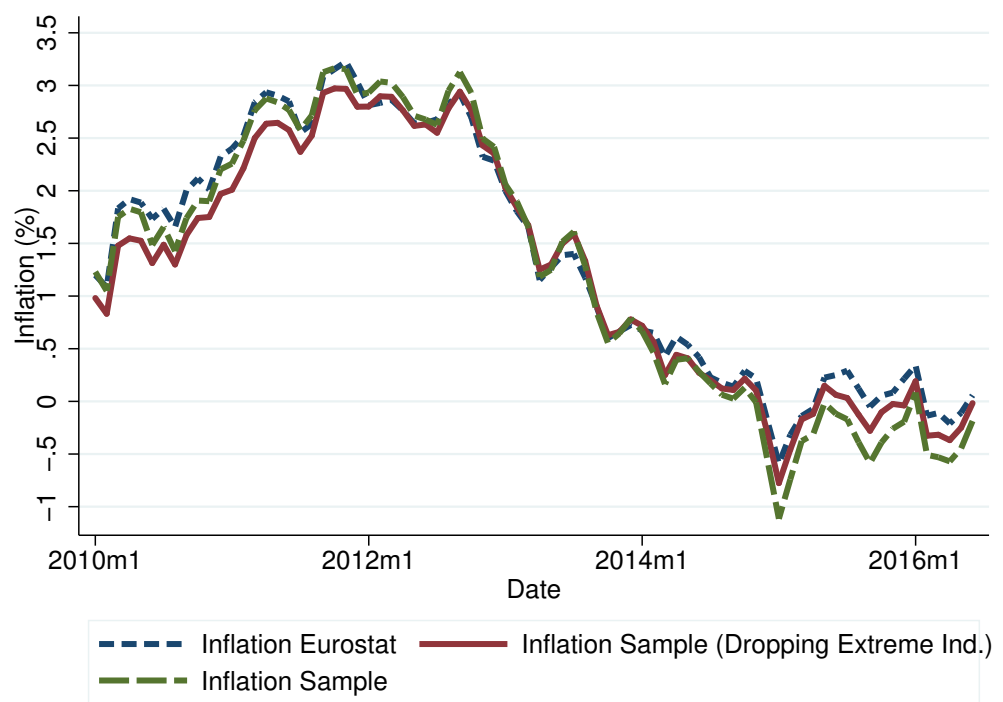

Figure B.1: Sample Vs. Official Inflation This figure shows evolution of the official inflation for our 12 sample countries from Eurostat (blue dashed line), the inflation aggregated from our industry-country dataset with (red solid line) and without (green dashed line) dropping extreme markets with less than -50\% or more than $+50 \%$ annual price growth.

\begin{tabular}{lcccc} 
& $\Delta \mathrm{CPI}$ & $\Delta \mathrm{CPI}$ & $\Delta \mathrm{CPI}$ & $\Delta \mathrm{CPI}$ \\
\hline Share Zombies & $-0.021^{* *}$ & $-0.018^{* *}$ & $-0.024^{* * *}$ & $-0.021^{* * *}$ \\
& $(0.008)$ & $(0.007)$ & $(0.009)$ & $(0.007)$ \\
\hline Observations & 3,833 & 3,833 & 3,833 & 3,833 \\
R-squared & 0.515 & 0.718 & 0.545 & 0.749 \\
\hline Country-Industry FE & $\checkmark$ & $\checkmark$ & $\checkmark$ & $\checkmark$ \\
Year FE & $\checkmark$ & & & \\
Industry-Year FE & & $\checkmark$ & & $\checkmark$ \\
Country-Year FE & & & $\checkmark$ & $\checkmark$ \\
\hline
\end{tabular}

Table B.1: Inflation: Industry-Country Evidence. This table presents industry-country-year level regressions. The dependent variable is the annual CPI growth rate (inflation) from $t$ to $t+1$. Share Zombies measures the asset-weighted share of zombie firms in a particular market at $t$. A firm is classified as zombie if it is low-quality and paid advantageous interest rates (see Section 4.2 for more details). Estimates show results after dropping extreme markets with less than $-50 \%$ or more than $+50 \%$ annual price growth. Standard errors are clustered at the industry-country level and reported in parentheses. $* * * \mathrm{p}<0.01, * *$ $\mathrm{p}<0.05,{ }^{*} \mathrm{p}<0.1$. 


\section{Appendix C Markup Estimation}

To obtain firm-level markups, we follow the procedure proposed by De Loecker and Warzynski (2012), which relies on the insight that the output elasticity of a variable production factor is only equal to its expenditure share in total revenue when price equals marginal cost of production. Under any form of imperfect competition, however, the relevant markup drives a wedge between the input's revenue share and its output elasticity.

In particular, this approach relies on standard cost minimization conditions for variable input factors free of adjustment costs. To obtain output elasticities, a production function has to be estimated. A major challenge is a potential simultaneity bias since the output may be determined by productivity shocks, which might be correlated with a firm's input choice.

To correct the markup estimates for unobserved productivity shocks, De Loecker and Warzynski (2012) follow the control function or proxy approach, developed by Ackerberg et al. (2006), based on Olley and Pakes (1996) and Levinsohn and Petrin (2003). This approach requires a production function with a scalar Hicks-neutral productivity term (i.e., changes in productivity do not affect the proportion of factor inputs) and that firms can be pooled together by time-invariant common production technology at the country-industry level.

Hence, we consider the case where in each period $t$, firm $i$ minimizes the contemporaneous production costs given the following production function:

$$
Q_{i t}=Q_{i t}\left(\Omega_{i t}, V_{i t}, K_{i t}\right)
$$

where $Q_{i t}$ is the output quantity produced by technology $Q_{i t}(\cdot), V_{i t}$ the variable input factor, $K_{i t}$ the capital stock (treated as a dynamic input in production), and $\Omega_{i t}$ the firm-specific Hicks-neutral productivity term. Following De Loecker and Eeckhout (2019), we assume that within a year the variable input can be adjusted without frictions, while adjusting the capital stock involves frictions.

As we assume that producers are cost minimizing, we are thus are left with the following 
Lagrangian function:

$$
\mathcal{L}\left(V_{i t}, K_{i t}, \lambda_{i t}\right)=P_{i t}^{V}+V_{i t}+r_{i t} K_{i t}+F_{i t}-\lambda_{i t}\left(Q(\cdot)-\bar{Q}_{i t}\right)
$$

where $P^{V}$ is the price of the variable input, $r$ is the user cost of capital, $F_{i t}$ is the fixed cost, and $\lambda_{i t}$ is the Lagrange multiplier. The first order condition with respect to the variable input $V$ is thus given by:

$$
\frac{\partial \mathcal{L}_{i t}}{\partial V_{i t}}=P_{i t}^{V}-\lambda_{i t} \frac{\partial Q(\cdot)}{\partial V_{i t}}=0
$$

Multiplying all terms by $V_{i t} / Q_{i t}$, and rearranging terms yields an expression for input $V$ 's output elasticity:

$$
\theta_{i t}^{v} \equiv \frac{\partial Q(\cdot)}{\partial V_{i t}} \frac{V_{i t}}{Q_{i t}}=\frac{1}{\lambda_{i t}} \frac{P_{i t}^{V} V_{i t}}{Q_{i t}} .
$$

As the Lagrange multiplier $\lambda$ is the value of the objective function as we relax the output constraints, it is a direct measure of the marginal costs. We thus define the markup as $\mu=P / \lambda$, where $P$ is the price for the output good, which depends on the extent of market power.

Substituting marginal costs for the markup/price ratio, we obtain a simple expression for the markup:

$$
\mu_{i t}=\theta_{i t}^{v} \frac{P_{i t} Q_{i t}}{P_{i t}^{V} V_{i t}} .
$$

Hence, there are two ingredients needed to estimate the markup of firm $i$ : its expenditure share of the variable input, $P_{i t} Q_{i t} / P_{i t}^{V} V_{i t}$, which is readily observable in the date, and its output elasticity of the variable input, $\theta_{i t}^{v}$.

To obtain an estimate of the output elasticity of the variable input of production, we estimate a parametric production function for each industry (at the two digits NACE level). 
For a given industry $h$ in country $j$, we consider the translog production function (TLPF): ${ }^{21}$

$$
q_{i t}=\beta_{v 1} v_{i t}+\beta_{k 1} k_{i t}+\beta_{v 2} v_{i t}^{2}+\beta_{k 2} k_{i t}^{2}+\omega_{i t}+\epsilon_{i t}
$$

where lower cases denote logs. ${ }^{22}$ In particular, $q_{i t}$ is the log of the realized firm's output (i.e., deflated turnover), $v_{i t}$ the log of the variable input factor (i.e., cost of goods sold and other operational expenditures), $k_{i t}$ the $\log$ of the capital stock (i.e., tangible assets), $\omega_{i}=\ln \left(\Omega_{i}\right)$, and $\epsilon_{i t}$ is the unanticipated shock to output. Moreover, we follow best practice and deflate these variables with the relevant industry-country specific deflator.

We follow the literature and control for the simultaneity and selection bias, inherently present in the estimation of Eq. (C6), and rely on a control function approach, paired with a law of motion for productivity, to estimate the output elasticity of the variable input.

This method relies on a so-called two-stage approach. In the first stage, the estimates of the expected output $\left(\widehat{\phi}_{i t}\right)$ and the unanticipated shocks to output $\left(\epsilon_{i t}\right)$ are purged using a non-parametric projection of output on the inputs and the control variable:

$$
q_{i t}=\phi_{i t}\left(v_{i t}, k_{i t}\right)+\epsilon_{i t}
$$

The second stage provides estimates for all production function coefficients by relying on the law of motion for productivity:

$$
\omega_{i t}=g_{t}\left(\omega_{i t-1}\right)+\varepsilon_{i t}
$$

We can compute productivity for any value of $\beta$, where $\beta=\left(\beta_{v 1}, \beta_{k 1}, \beta_{v 2}, \beta_{k 2}\right)$, using $\omega_{i t}(\beta)=$ $\widehat{\phi}\left(\beta_{v 1} v_{i t}+\beta_{k 1} k_{i t}+\beta_{v 2} v_{i t}^{2}+\beta_{k 2} k_{i t}^{2}\right)$.

\footnotetext{
${ }^{21}$ The TLPF is a common technology specification that includes higher order terms that is more flexible than, e.g., a Cobb-Douglas production function. The departure from the standard Cobb-Douglas production function is important for our purpose. If we were to restrict the output elasticities to be independent of input use intensity when analyzing how markup differs across firms, we would be attributing variation in technology to variation in markups, and potentially bias our results. (e.g., when comparing zombie vs non-zombie firms).

${ }^{22}$ We follow De Loecker and Eeckhout (2019) and do not consider the interaction term between $v$ and $k$ to minimize the potential impact of measurement error in capital to contaminate the parameter of most interest, i.e., the output elasticity.
} 
By nonparametrically regressing $\omega_{i t}(\beta)$ on its lag, $\omega_{i t-1}(\beta)$, we recover the innovation to productivity given $\beta, \varepsilon_{i t}(\beta)$.

This gives rise to the following moment conditions, which allow us to obtain estimates of the production function parameters:

$$
E\left(\varepsilon_{i t}(\beta)\left(\begin{array}{c}
v_{i t-1} \\
k_{i t} \\
v_{i t-1}^{2} \\
k_{i t}^{2}
\end{array}\right)\right)=0
$$

where we use standard GMM techniques to obtain the estimates of the production function and rely on block bootstrapping for the standard errors. These moment conditions exploit the fact that the capital stock is assumed to be decided a period ahead and thus should not be correlated with the innovation in productivity. We rely on the lagged variable input to identify the coefficients on the current variable input since the current variable input is expected to react to shocks to productivity.

The estimated output elasticities are computed using the estimated coefficients of the production function:

$$
\theta_{i t}^{v}=\widehat{\beta}_{v 1}+2 \widehat{\beta}_{v 2} v_{i t}
$$

which allows us to calculate the markup of firm $i$. 